\title{
A Novel Salt Bridge Mechanism Highlights the Need for Nonmobile Proton Conditions to Promote Disulfide Bond Cleavage in Protonated Peptides Under Low-Energy Collisional Activation
}

\author{
Hadi Lioe ${ }^{\mathrm{a}, \mathrm{b}}$ and Richard A. J. O'Hair ${ }^{\mathrm{a}, \mathrm{c}}$ \\ a School of Chemistry, University of Melbourne, Melbourne, Australia \\ ${ }^{\mathrm{b}}$ Bio21 Institute of Molecular Science and Biotechnology, University of Melbourne, Melbourne, Australia \\ ${ }^{c}$ ARC Centre of Excellence in Free Radical Chemistry and Biotechnology
}

The gas-phase fragmentation mechanisms of small models for peptides containing intermolecular disulfide links have been studied using a combination of tandem mass spectrometry experiments, isotopic labeling, structural labeling, accurate mass measurements of product ions, and theoretical calculations (at the MP2/6-311 + G(2d,p)//B3LYP/3-21G(d) level of theory). Cystine and its $\mathrm{C}$-terminal derivatives were observed to fragment via a range of pathways, including loss of neutral molecules, amide bond cleavage, and S-S and C-S bond cleavages. Various mechanisms were considered to rationalize S-S and C-S bond cleavage processes, including charge directed neighboring group processes and nonmobile proton salt bridge mechanism. Three low-energy fragmentation pathways were identified from theoretical calculations on cystine N-methyl amide: (1) S-S bond cleavage dominated by a neighboring group process involving the C-terminal amide $\mathrm{N}$ to form either a protonated cysteine derivative or protonated sulfenyl amide product ion $\left(44.3 \mathrm{kcal} \mathrm{mol}^{-1}\right)$; (2) C-S bond cleavage via a salt bridge mechanism, involving abstraction of the $\alpha$-hydrogen by the $\mathrm{N}$-terminal amino group to form a protonated thiocysteine derivative $\left(35.0 \mathrm{kcal} \mathrm{mol}^{-1}\right)$; and (3) C-S bond cleavage via a Grob-like fragmentation process in which the nucleophilic N-terminal amino group forms a protonated dithiazolidine $\left(57.9 \mathrm{kcal} \mathrm{mol}^{-1}\right)$. Interestingly, $\mathrm{C}-\mathrm{S}$ bond cleavage by neighboring group processes have high activation barriers $\left(63.1 \mathrm{kcal} \mathrm{mol}^{-1}\right)$ and are thus not expected to be accessible during low-energy CID experiments. In comparison to the energetics of simple amide bond cleavage, these S-S and C-S bond cleavage reactions are higher in energy, which helps rationalize why bond cleavage processes involving the disulfide bond are rarely observed for low-energy CID of peptides with mobile proton(s) containing intermolecular disulfide bonds. On the other hand, the absence of a mobile proton appears to "switch on" disulfide bond cleavage reactions, which can be rationalized by the salt bridge mechanism. This potentially has important ramifications in explaining the prevalence of disulfide bond cleavage in singly protonated peptides under MALDI conditions. (J Am Soc Mass Spectrom 2007, 18, 1109-1123) (c 2007 American Society for Mass Spectrometry

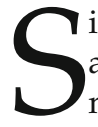
ide chain cleavage reactions can compete with, and sometimes dominate over, sequence ion formation in the tandem mass spectra of protonated [1, 2] and deprotonated [3] peptides. Given that over 300 post-translational modifications (PTM) had been identified [4], these reactions can greatly help identify post-translationally modified residues via the loss of diagnostic small molecules. For example, the losses of

This article is Part 54 of the series "Gas Phase Ion Chemistry of Biomolecules."

Presented in part at the 54th American Society for Mass Spectrometry (ASMS) Conference, Seattle, Washington, May 28-June 1, 2006.

Address reprint requests to Professor Richard O'Hair, School of Chemistry, University of Melbourne, Parkville, Victoria 3010, Australia. E-mail: rohair@unimelb.edu.au
$\mathrm{H}_{3} \mathrm{PO}_{4}[5]$ and $\mathrm{CH}_{3} \mathrm{SOH}[6,7]$ in the MS/MS of protonated peptides are indicators of phosphorylation and methionine sulfoxide formation, respectively. Progress has been made in understanding the factors that govern these reactions through a combination of mechanistic studies [1, 2, 6, 8] and interrogation of databases of tandem mass spectra [7]. Several different types of mechanisms may operate depending on the structure and properties of the peptide. For example, studies on simple derivatives of O-phosphoserine reveal that $\mathrm{H}_{3} \mathrm{PO}_{4}$ loss can occur via the following: charge directed neighboring group process (path $\mathrm{A}$ of Scheme 1, $\mathrm{X}=$ $\mathrm{H}_{2} \mathrm{PO}_{4}$ ); and charge remote internal elimination reaction to form a dehydroalanine residue (path $\mathrm{B}$ of Scheme 1, $\mathrm{X}=\mathrm{H}_{2} \mathrm{PO}_{4}$ ) [8]. These different pathways can 

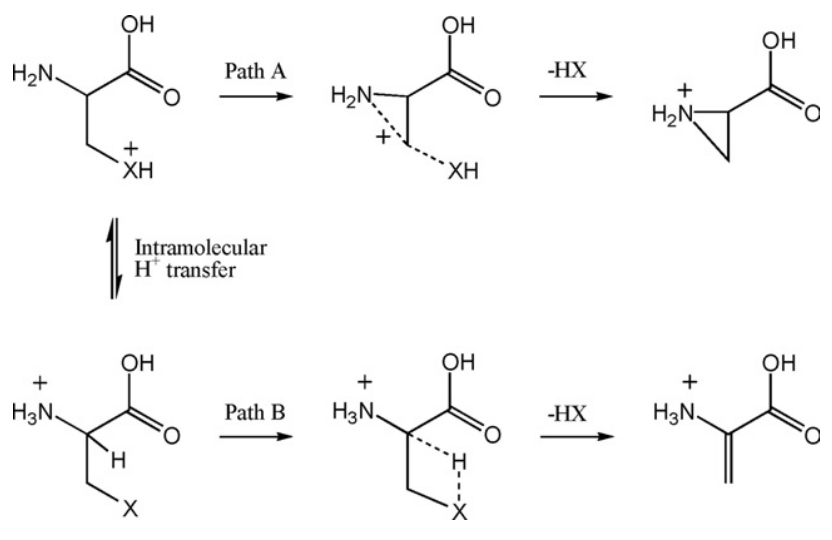

Scheme 1

be experimentally distinguished via deuterium labeling studies, and theoretical calculations provide information on the relative energies of the potential energy surfaces of these reactions. For example, in O-phosphoserine, when all exchangeable hydrogens are replaced by deuterium, $\mathrm{D}_{3} \mathrm{PO}_{4}$ is lost, indicating that the neighboring group process operates. Theoretical calculations also confirm that the barrier to the neighboring group process is lower in energy.

Another interesting class of side-chain cleavage reactions involving PTM is disulfide bond cleavage. Unlike O-phosphoserine and methionine sulfoxide, however, disulfide bond cleavage is generally not readily observed under low-energy CID conditions, hindering the identification of primary structure of peptides, especially if the peptide is contained within the disulfide loop [9]. Although there has been considerable interest in developing methods to target and cleave disulfide bonds in peptides [10-14], remarkably little work has been carried out to establish what factors govern disulfide bond cleavage, (which can either involve $\mathrm{S}-\mathrm{S}$ or $\mathrm{C}-\mathrm{S}$ bond cleavage), in the low-energy CID spectra of protonated peptides. It has been noted by Jones et al. [15] and McLuckey [16] that the abundance of disulfide bond cleavage is dependent on the number of charges on the peptide. For example, the $[\mathrm{M}+4 \mathrm{H}]^{4+}$ and $[\mathrm{M}+5 \mathrm{H}]^{5+}$ ions of insulin exclusively fragment via peptide bond cleavage, whereas the $[\mathrm{M}+\mathrm{H}]^{+}$ion fragments via competitive disulfide bond cleavage and C-terminal glutamic acid amide bond cleavage [16]. Thus, the absence of a mobile proton $[17,18]$ appears to facilitate disulfide bond cleavage. The mechanistic features of these bond cleavage reactions have not been well established, although we were intrigued by a recent report [19], which proposed that S-S bond cleavage leads to the formation of a sulfenylium ion $\left(\mathrm{R}-\mathrm{S}^{+}\right)$ and that $\mathrm{C}-\mathrm{S}$ bond cleavage forms the R-S-S ${ }^{+}$product ion. Given that $\mathrm{RS}^{+}$cations are not very stable [20], the formation of cyclic product ions via neighboring group processes [6] seemed more likely.

Here we investigate disulfide bond cleavage reactions in small models for peptides containing intermolecular disulfide links under conditions of low-energy collision induced dissociation (CID). A combination of physical organic chemistry tools was utilized, including isotopic labeling, structural labeling, accurate mass measurements of product ions, and DFT calculations. The latter provide insights into the fragmentation mechanisms of S-S and C-S bond cleavage reactions. Various mechanisms for S-S and C-S bond cleavage reactions were interrogated and their relative likelihood of occurring was determined via a comparison of the energetics associated with the reactions coordinates for the model system, cystine N-methyl amide. Finally, the energetic requirement to cleave the disulfide bonds of model peptides were compared with that of amide bond cleavage processes.

\section{Experimental}

\section{Materials}

The disulfide bond cleavage reactions were studied using model systems of cysteine (Cys), cysteine derivatives (CysOMe, CysNHMe, AcCys, NMeCys, AcCysOMe, AcCysNHMe, AcCG), and cysteine-containing small peptides (CG, GC, GCG, GGC, GSSG). All reagents were also used as supplied: $\mathrm{Cys}, \mathrm{CysOMe}, \mathrm{AcCys},(\mathrm{AcCysOMe})_{-2-}$, and GSSG were purchased from Sigma-Aldrich (St. Louis, MO); CG, GC, GCG, and GGC were purchased from BaChem (Bubendorf, Switzerland); and $\mathrm{D}_{2}$-cysteine $\left[\mathrm{H}_{2} \mathrm{NCH}\left(\mathrm{CD}_{2} \mathrm{SH}\right) \mathrm{CO}_{2} \mathrm{H}(98 \% \mathrm{D})\right]$ was obtained from Cambridge Isotope Laboratories. N-methyl cysteine was available from a previous study [21].

\section{Modifications of Cysteine and Cysteine Derivatives}

$N$-acetylation and O-methyl esterification of cysteine derivatives. We have used the general procedure for $\mathrm{N}$ acetylation and O-Methyl esterification of amino acids and peptides [22].

$N$-methyl amidation of cysteine and cystine derivatives. We have used the method of Feenstra et al. [23] for methyl amidation of cysteine and cystine derivatives from the methyl ester. Briefly, $2 \mathrm{mg}$ of the methyl ester of cysteine and cystine derivatives were dissolved in $1 \mathrm{~mL}$ of $30 \%$ aqueous $\mathrm{CH}_{3} \mathrm{NH}_{2}$ solution and the reaction was allowed to proceed at room temperature for $30 \mathrm{~min}$. The mixture was dried by freeze drying, dissolved in 50\% $\mathrm{CH}_{3} \mathrm{OH} / 50 \% \mathrm{H}_{2} \mathrm{O}$ containing $0.1 \mathrm{M}$ acetic acid, and then lyophilized again. The methyl amide was used without further purification.

\section{Oxidation of Cysteine Derivatives to Cystine Derivatives}

Individual solutions of peptide containing cysteine residue were auto-oxidized in a $10 \mathrm{mM}$ aqueous solution for 7 days to its cystine counterpart. Although we have not followed the auto-oxidation kinetics, these reactions essentially proceeded to completion, as judged by ESI 
mass spectra. They were then diluted to a final total concentration of $\sim 0.1 \mathrm{mM}$ in $50 \% \mathrm{CH}_{3} \mathrm{OH} / 50 \% \mathrm{H}_{2} \mathrm{O}$ solution containing $0.1 \mathrm{M}$ acetic acid.

\section{Mass Spectrometry Experiments}

All experiments were carried out using a modified commercial ion trap mass spectrometer equipped with electrospray ionization (ESI) (Finnigan-MAT LCQ Classic; ThermoElectron Corp., San Jose, CA). The samples were introduced to the mass spectrometer at a flow rate of $3 \mu \mathrm{L} / \mathrm{min}$. The sheath air, capillary voltage, and temperature were adjusted to ca. $30-60,4.5$ to $5.0 \mathrm{kV}$, and $180{ }^{\circ} \mathrm{C}$, respectively. The CID experiments were performed using standard procedures by mass selecting the desired precursor ion, with an activation window of 2 to $3 \mathrm{~m} / \mathrm{z}$, and then subjecting it to CID using normalized collision energy of 12.5 to $18.5 \%$ and an activation $\mathrm{Q}$ of 0.25 for a period of $30 \mathrm{~ms}$.

\section{High-Resolution Mass Spectrometry Experiments}

All high-resolution mass spectrometry experiments were conducted using a commercially available hybrid linear ion trap and Fourier transform ion cyclotron resonance (FT-ICR) mass spectrometer (Finnigan LTQFT; ThermoElectron Corp.), which is equipped with ESI. The samples were introduced to the mass spectrometer via direct injection through electrospray ionization using a flow rate of $3.5 \mu \mathrm{L} / \mathrm{min}$. The sheath air, capillary voltage, and temperature were adjusted to ca. 2.5 to $25,4.0$ to $4.5 \mathrm{kV}$, and $275^{\circ} \mathrm{C}$, respectively. The CID experiments were performed in the linear ion trap by using standard procedures of mass selecting the desired precursor ion, with an activation window of 2.5 to 2.9 $\mathrm{m} / \mathrm{z}$, and then subjecting it to CID using a corresponding normalized collision energy of 25 to $34 \%$ and an activation $\mathrm{Q}$ of 0.25 for a period of $30 \mathrm{~ms}$. The product ions were then analyzed in the FT-ICR MS to generate the high-resolution tandem mass spectrum. The instrument was externally calibrated using the standard calibration solution recommended by the manufacturer (a mixture of caffeine, MRFA, and Ultramark 1621) and standard procedure before analysis. All product ions of interest register a relative error in their exact masses of $<0.7$ ppm when compared with their predicted molecular formulas.

\section{Calculation of Percentage of Different Bond Cleavages}

We have used the formula shown in eq 1 to calculate S-S and C-S bond cleavage processes and "other bond cleavage" processes. The latter processes comprise of neutral molecule elimination and amide bond cleavage. $\mathrm{X}-\mathrm{X}$ bond cleavage corresponds to specific bond cleavage process together with any product ions arising from subsequent fragmentation. We have not used the high- resolution MS data to calculate ion abundance as there appears to be a time-of-flight effect that results in discrimination of low mass ions.

$$
\begin{aligned}
& \% \text { of } X-X \text { bond cleavage from } M S / M S \text { experiment } \\
&=(\Sigma \text { ion abundance for } X-X \text { bond cleaveage }) / \\
&(\Sigma \text { all product ion abundance }) \times 100 \%
\end{aligned}
$$

\section{Theoretical Calculations}

Due to the large size of the system, it was not feasible to optimize all species on the potential energy surfaces for the competing fragmentation reactions of protonated cystine N-methyl amide at the B3LYP/6-31 + G(d,p) level of theory. Thus, a survey of different levels of theory was carried out on the model systems $\left[\mathrm{H}_{3} \mathrm{NCH}\left(\mathrm{CH}_{2} \mathrm{SSX}\right) \mathrm{CONHMe}\right]\left(\mathrm{X}=\mathrm{H}\right.$ and $\left.\mathrm{CH}_{3}\right)$. We established that single point energy calculations at the $\mathrm{MP} 2 / 6-311+\mathrm{G}(2 \mathrm{~d}, \mathrm{p})$ on B3LYP/3-21G(d) optimized structures with B3LYP/3-21G(d) zero point energy corrections gave similar results to those of the much more computationally expensive B3LYP/6-31 + G(d,p) optimizations and zero point energy corrections. Geometry optimizations for minima and transition states were carried ${ }^{\circ}$ out $^{\circ}$ using ${ }^{\circ}$ the ${ }^{\circ}$ Gaussian $^{\circ} 03^{\circ}[24]^{\circ}$ molecular ${ }^{\circ}$ modeling package to gain further insights into different mechanisms by calculating the transition-state structures. Transition-state structures were connected to the minima using standard intrinsic reaction coordinate (IRC) calculations. The single point energy of all structures were further calculated at the MP2/6-311 + $\mathrm{G}(2 \mathrm{~d}, \mathrm{p})^{\circ} \mathrm{level}^{\circ}$ of $^{\circ}$ theory ${ }^{\circ}[25]^{\circ}{ }^{\circ}$ All $^{\circ}$ optimized $^{\circ}$ structures were subjected to vibrational frequency analysis to confirm that the optimized structures are local/global minima (no imaginary frequency) or transition state (one imaginary frequency) and visualized using the computer ${ }^{\circ}$ package ${ }^{\circ}$ Gauss View $^{\circ} 3.0^{\circ}[26]$.

The supplementary material is available in the electronic version of this article for:

(1) high-resolution MS/MS spectra of protonated $(\mathrm{CysOH})_{2},(\mathrm{CysOMe})_{2},(\mathrm{CysNHMe})_{2}$, and $(\mathrm{CG})_{2}$;

(2) CID MS/MS of some cystine derivatives;

(3) optimized structures for other calculated pathways to cleave S-S bond (path SSA and SSC) and C-S bond (path CSA, CSB, $\mathrm{CS}_{\mathrm{g}} \mathrm{B}$, and $\mathrm{CS}_{\mathrm{g}} \mathrm{C}$ );

(4) complete structural details for each of the B3LYP/ 3-21G(d) optimized structures.

\section{Results and Discussion}

Fragmentation Studies of Cystine Derivatives, $(\mathrm{X}-\mathrm{Cys}-\mathrm{Y})_{2}(\mathrm{X}=\mathrm{H}, \mathrm{Y}=\mathrm{OH}, \mathrm{OMe}$, and $\mathrm{NHMe})$ and Cystine-Containing Simple Peptides, $(\mathrm{CG})_{2}$, $(G C)_{2},(G C G)_{2}$, and $(G C R)_{2}$

The CID spectra of protonated cystine $\left[(\mathrm{CysOH})_{2}\right]$, several derivatives of cystine, and a number of cystine- 

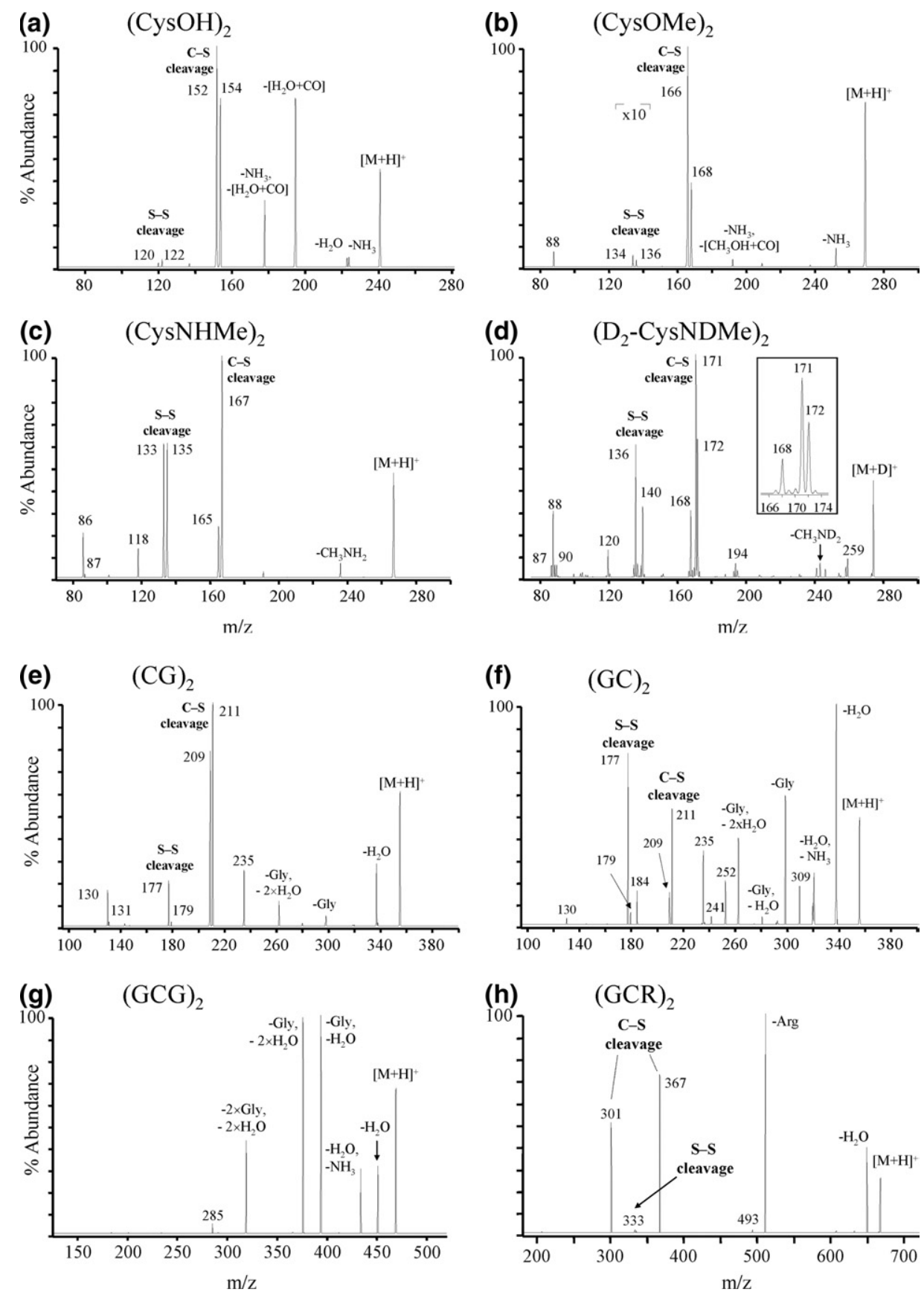

Figure 1. CID MS/MS spectra of cystine and its simple C-terminal derivatives and cystinecontaining peptides: (a) $[\mathrm{M}+\mathrm{H}]^{+}$of $(\mathrm{CysOH})_{2}$, (b) $[\mathrm{M}+\mathrm{H}]^{+}$of $(\mathrm{CysOMe})_{2}$, (c) $[\mathrm{M}+\mathrm{H}]^{+}$of $(\text { CysNHMe })_{2},(\mathbf{d})[\mathrm{M}+\mathrm{D}]^{+}$of $\left(\mathrm{D}_{2}-\mathrm{CysNDMe}\right)_{2},(\mathbf{e})[\mathrm{M}+\mathrm{H}]^{+}(\mathrm{CG})_{2},(\mathbf{f})[\mathrm{M}+\mathrm{H}]^{+}$of $(\mathrm{GC})_{2},(\mathrm{~g})[\mathrm{M}+$ $\mathrm{H}]^{+}$of $(\mathrm{GCG})_{2}$, and $(\mathrm{h})[\mathrm{M}+\mathrm{H}]^{+}$of $(\mathrm{GCR})_{2}$. For $\left(\mathrm{D}_{2}-\mathrm{CysNDMe}\right)_{2}$ the experiment was performed under $\mathrm{H} / \mathrm{D}$ exchange conditions, whereby all acidic hydrogens were substituted with deuterium,

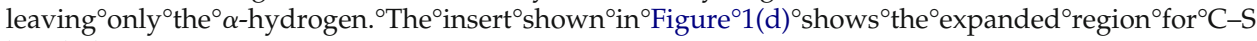
bond cleavage.

containing ${ }^{\circ}$ peptides ${ }^{\circ}$ are $^{\circ}$ shown $^{\circ}$ in $^{\circ}$ Figure $^{\circ} 1$. In $^{\circ}$ addition, the CID spectra of several other cystine derivatives and cystine-containing peptides are shown in the supplementary ${ }^{\circ}$ material. ${ }^{\circ}$ For $^{\circ}$ Cystine $^{\circ}\left(\right.$ Figure $\left.^{\circ} 1 \mathrm{a}\right),{ }^{\circ}$ several ${ }^{\circ}$ sim- $^{-}$ ple neutral molecule losses are observed, including losses of $\mathrm{NH}_{3}, \mathrm{H}_{2} \mathrm{O},\left[\mathrm{H}_{2} \mathrm{O}+\mathrm{CO}\right]$, and $\mathrm{NH}_{3}+\left[\mathrm{H}_{2} \mathrm{O}+\right.$ $\mathrm{CO}$. In addition, product ions at $\mathrm{m} / \mathrm{z} 120$ and 122, and $\mathrm{m} / \mathrm{z} 152$ and 154 are observed, and these arise from S-S and $\mathrm{C}-\mathrm{S}$ bond cleavage, respectively. This was further confirmed from accurate mass measurements (Figures S1a-d see supplementary Figures S1a-d), where it was found that these product ions have molecular formulas consistent with symmetric S-S and asymmetric $\mathrm{C}-\mathrm{S}$ bond cleavage processes. The modified 
C-terminal ${ }^{\circ}$ cystine $^{\circ}$ derivatives $^{\circ}\left(\right.$ Figure $^{\circ} 1 b^{\circ},{ }^{\circ},{ }^{\circ}$ and $\left.^{\circ} \mathrm{e}\right)$ fragment in a similar fashion with the formation of product ions due to S-S and C-S bond cleavage being shifted to higher $\mathrm{m} / \mathrm{z}$ values attributable to the Cterminal modification [e.g., for $(\mathrm{CysOMe})_{2}$ these product ions are shifted upfield by $14 \mathrm{Da}$, for (CysNHMe $)_{2}$ by $13 \mathrm{Da}$, and for $(\mathrm{CG})_{2}$ by $57 \mathrm{Da}$. For $(\mathrm{CysOMe})_{2}$ and $(\mathrm{CysNHMe})_{2}$ the formation of the S-S and C-S fragment ions almost dominate the MS/MS spectra.

Isotopic labeling studies of $\left(\mathrm{D}_{2}-\mathrm{CysNHMe}\right)_{2}$, where all hydrogen except for $\alpha$-hydrogen has been substituted with deuterium to form $\left(\mathrm{D}_{2}-\mathrm{CysNDMe}\right)_{2}$, shows a small amount of scrambling occurring before fragmentation, as indicated by a series of product ions that form the triplets (centered at $m / z 88,136,168$, and 194) shown in $^{\circ}$ Figure $^{\circ} 1 \mathrm{~d}$. ${ }^{\circ}$ More $^{\circ}$ interestingly, ${ }^{\circ} \mathrm{C}-\mathrm{S}^{\circ}$ bond ${ }^{\circ}$ cleavage process undergoes more extensive scrambling to form the unexpected but dominant product ion at $\mathrm{m} / \mathrm{z} 171$. The $^{\circ}$ insert $^{\circ}$ in $^{\circ}$ Figure $^{\circ} 1 \mathrm{~d}^{\circ}$ shows $^{\circ}$ the ${ }^{\circ}$ expanded ${ }^{\circ}$ region of the $\mathrm{C}-\mathrm{S}$ bond cleavage process. Hence, the $\mathrm{C}-\mathrm{S}$ bond cleavage reaction appears to involve the $\alpha$-hydrogen.

Figure $^{\circ} 1 \mathrm{f}-\mathrm{h}^{\circ}$ shows $^{\circ}$ the ${ }^{\circ} \mathrm{MS} / \mathrm{MS}^{\circ}$ spectra ${ }^{\circ}$ of ${ }^{\circ}$ simple peptides containing cystine, in which the disulfide bond is not at the N-terminal of the peptide. Unlike the other cystine $^{\circ}$ derivatives ${ }^{\circ}$ shown $^{\circ}$ in ${ }^{\circ}$ Figure $^{\circ} 1 \mathrm{a}-\mathrm{e}^{\circ}$ where ${ }^{\circ}$ the disulfide bond is at the $\mathrm{N}$-terminus, the fragmentation is dominated by neutral molecule losses and amide bond cleavages. In addition, with the exception of protonated (GC) ${ }_{2}$ shown ${ }^{9}$ in Figure $1 \mathrm{f}, \mathrm{S}^{\mathrm{S}}-\mathrm{S}^{\circ}$ and ${ }^{\circ} \mathrm{C}-\mathrm{S}$ bond cleavage processes are absent. This fragmentation behavior is consistent with the observation that disulfide bond cleavage in the fragmentation of larger tryptic peptides containing disulfide bond are rarely observed [9], , suggesting $^{\circ}$ that ${ }^{\circ}$ disulfide $^{\circ}$ bond $^{\circ}$ cleavage $^{\circ}$ processes have higher relative energy barriers compared with amide bond cleavages. This example is best illustrated by the fragmentation of protonated (GCG) ${ }_{2}$, which fragments under low-energy CID to mainly eliminate small molecules and various combinations of glycyl residue and $\mathrm{H}_{2} \mathrm{O}^{\circ}$ (Figure ${ }^{\circ} 1 \mathrm{~g}$ ). ${ }^{\circ}$ When ${ }^{\circ}$ fragmentation occurs under nonmobile proton condition, as in the case of protonated $(\mathrm{GCR})_{2}, \mathrm{C}-\mathrm{S}$ bond cleavage is readily observed $^{\circ}\left(\mathrm{m} / \mathrm{z} 367^{\circ} \text { and }^{\circ} 301\right)^{\circ}\left(\right.$ see $^{\circ}$ Figure $\left.^{\circ} 1 \mathrm{~h}\right) .^{\circ}$ The $^{\circ}$ only other fragmentation processes observed are $\mathrm{H}_{2} \mathrm{O}$ loss, loss of Arg residue, and a very small amount of S-S bond cleavage. Thus, the absence of a mobile proton appears to have a profound influence on disulfide bond cleavage.

The fragmentation of all cystine derivatives studied are $^{\circ}$ summarized ${ }^{\circ}{ }^{\circ}{ }^{\circ}$ Table $^{\circ} 1$, ${ }^{\circ}$ showing ${ }^{\circ}$ the ${ }^{\circ}$ percentage ${ }^{\circ}$ of processes due to $\mathrm{S}-\mathrm{S}$ bond cleavage, $\mathrm{C}-\mathrm{S}$ bond cleavage, and other bond cleavage processes (small neutral loss and $^{\circ}$ amide ${ }^{\circ}$ bond ${ }^{\circ}$ cleavage)..$^{\circ} t^{\circ} \mathrm{can}^{\circ} \mathrm{be}^{\circ}$ seen $^{\circ}$ from ${ }^{\circ} \mathrm{Table}^{\circ} 1$ that most disulfide bond cleavage reactions (S-S and C-S bond cleavages) are observed only for the small cystine derivatives, especially if the disulfide bond is at the $\mathrm{N}$-terminus. To provide further insights into disulfide bond cleavage reactions, and to understand why disulfide bonds are not easily cleaved for large peptides with mobile proton(s), we performed theoretical calcu-
Table 1. Percentage of bond cleavage in the CID fragmentation of all peptides studied that contain a cystine moiety

\begin{tabular}{cccr}
\hline $\begin{array}{c}\text { Peptide } \\
\text { derivatives }\end{array}$ & $\begin{array}{c}\text { S-S of } \\
\text { cleavage }\end{array}$ & $\begin{array}{c}\text { \% of } \\
\text { C-S bond } \\
\text { cleavage }\end{array}$ & $\begin{array}{c}\text { \% of } \\
\text { other } \\
\text { processes }\end{array}$ \\
\hline \hline $\begin{array}{c}\text { (Cys) })_{2} \\
(\text { CysOMe) }\end{array}$ & 1.8 & 58.8 & 39.4 \\
$(\text { CysNHMe })_{2}$ & 0.5 & 90.4 & 9.0 \\
$(\mathrm{NMeCysOH})_{2}$ & 0.9 & 49.4 & 3.7 \\
$(\mathrm{AcCysOH})_{2}$ & 0.0 & 100 & 0.0 \\
$(\mathrm{AcCysOMe})_{2}$ & 1.1 & 0.0 & 100.0 \\
$(\mathrm{AcCysNHMe})_{2}$ & 0.0 & 0.0 & 98.9 \\
$(\mathrm{AcCG})_{2}$ & 0.0 & 0.0 & 100.0 \\
$(\mathrm{CG})_{2}$ & 8.0 & 0.0 & 100.0 \\
$(\mathrm{GC})_{2}$ & 17.2 & 67.7 & 24.3 \\
$(\mathrm{GCG})_{2}$ & 0.0 & 14.6 & 68.2 \\
$(\mathrm{GGC})_{2}$ & 0.0 & 0.0 & 100.0 \\
$\mathrm{GSSG}$ & 0.0 & 0.0 & 100.0 \\
$(\mathrm{GCR})_{2}$ & 0.9 & 0.0 & 100.0 \\
& & 46.5 & 52.6 \\
\hline
\end{tabular}

lations to investigate the different fragmentation pathways, and these are described in later sections.

\section{Various Mechanisms for S-S and C-S Bond Cleavage Reactions}

Since our previous studies had demonstrated that charge directed neighboring group processes are energetically favorable for amino acid and peptide ion fragmentation $\left[8,{ }^{\circ} 27,28\right],{ }^{\circ}$ we $^{\circ}$ proposed ${ }^{\circ} \mathrm{a}^{\circ}$ similar ${ }^{\circ}$ mechanism for $\mathrm{S}-\mathrm{S}$ bond cleavage processes shown in Scheme 2, i.e., neighboring group attack by N-terminal amino $\mathrm{N}$ (path SSA), C-terminal amide $\mathrm{N}$ (path SSB), or C-terminal carbonyl $\mathrm{O}$ (path SSC) to $\gamma$-sulfur of S-protonated $(\mathrm{Cys} X)_{2}$, where $\mathrm{X}=\mathrm{OH}, \mathrm{OMe}, \mathrm{NHMe}$, or Gly. During the S-S bond cleavage process an ionmolecule ${ }^{\circ}$ complex $^{\circ}[29]^{\circ}$ is $^{\circ}$ formed ${ }^{\circ}$ during $^{\circ}$ which ${ }^{\circ}$ proton transfer process can occur to form cyclic product ions $(C),(E)$, or $(\mathbf{F})$, or protonated cysteine derivative (D), depending on the proton affinity of the individual neutral ${ }^{\circ}$ fragment ${ }^{\circ}[30]^{\circ} .^{\circ} \mathrm{We}^{\circ}$ should ${ }^{\circ}$ note ${ }^{\circ}$ that ${ }^{\circ}$ these ${ }^{\circ}$ bond cleavage processes are preceded by an intramolecular proton transfer from N-terminal amino group to the disulfide group, which unfortunately could not be located at the B3LYP/3-21G(d) level of theory. However, it is expected that the intramolecular proton transfer process to be lower in energy than bond cleavage processes. It should be noted that Structure $\mathbf{F}$ is related to one of the neutral structures previously proposed ${ }^{\circ}$ for $^{\circ} \mathrm{S}-\mathrm{S}^{\circ}$ bond $^{\circ}{ }^{\circ}$ leavage ${ }^{\circ}$ products $^{\circ}[19]$.

For $\mathrm{C}-\mathrm{S}$ bond cleavage, we proposed three competing mechanisms: (1) charge directed neighboring group processes summarized in Scheme 3, (2) fragmentation involving the formation of salt bridge intermediate shown in Scheme 4, and (3) charge directed Grob-type fragmentation ${ }^{\circ}\left[31,{ }^{\circ} 32\right]^{\circ}$ summarized $^{\circ}$ in $^{\circ}$ Scheme $^{\circ} 5$. $^{\circ}$ For charge directed neighboring group mechanisms shown in Scheme 3, C-S bond cleavage is effected by nucleophilic attack by either the: N-terminal amino $\mathrm{N}$ (path 


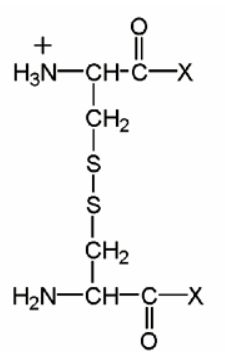

(A)

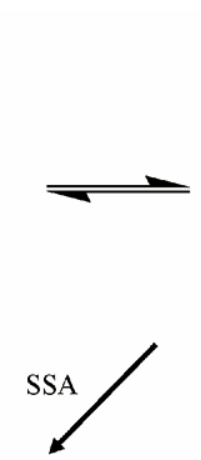

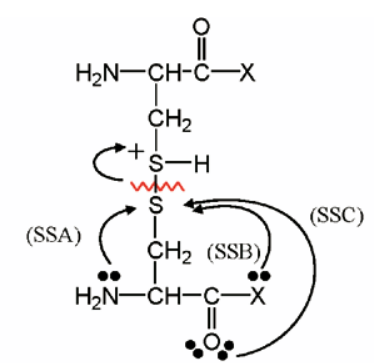

(B)
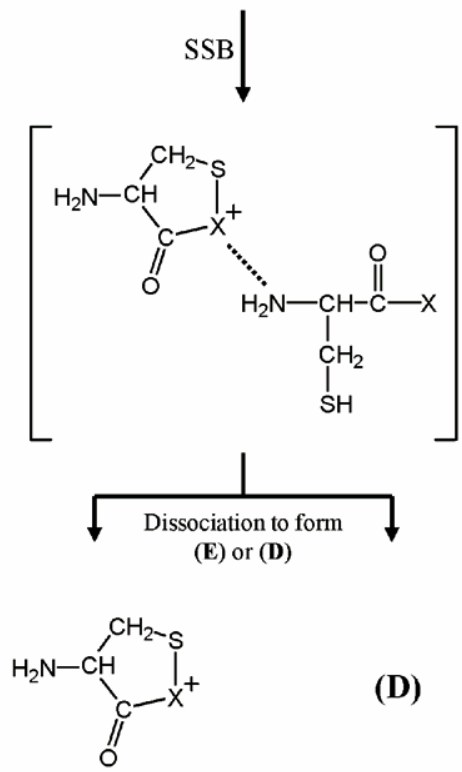

(E)
$\mathrm{X}=\mathrm{OH}$,

$\mathrm{OCH}_{3}$,

$\mathrm{NHCH}_{3}$,

Gly

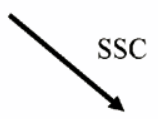

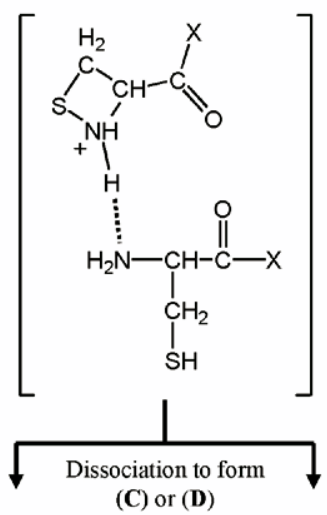<smiles>[X]C(=O)C1CSN1</smiles>

(C)

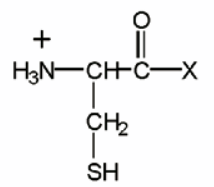

(D)
(D)

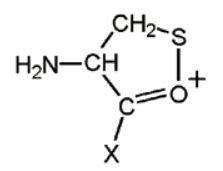

(D)

Scheme 2. S-S (NG).

CSA) (c.f. path A of Scheme 1); C-terminal amide N (path CSB); or C-terminal carbonyl O (path CSC) to $\beta$-carbon of S-protonated cystine derivative. These reactions form cyclic product ions $(\mathbf{G})$, (I), or $(\mathbf{J})$, or protonated S-thio-cysteine derivative $(\mathbf{H})$.

To explain the scrambling observed in C-S bond cleavage $^{\circ}$ in $^{\circ}$ deuterated ${ }^{\circ}\left(\mathrm{D}_{2}-\text { CysNDMe }\right)_{2^{\circ}}\left(\right.$ Figure $\left.^{\circ} 1 \mathrm{~d}\right),{ }^{\circ}$ we $^{\circ}$ proposed a mechanism to cleave the $\mathrm{C}-\mathrm{S}$ bond, which involves the $\alpha$-hydrogen before fragmentation (Scheme 4). In this mechanism, $\mathrm{C}-\mathrm{S}$ bond cleavage is instigated by abstraction of the $\alpha$-hydrogen by the basic N-terminal amino group from the opposite backbone, which forms a salt bridge ion-molecule complex. Intramolecular proton transfer within the ion-molecule complex would then yield either protonated dehydroalanine derivative (Structure K) or protonated S-thio-cysteine derivative (H). For this mechanism, the charge is located at the $\mathrm{N}$-terminal amino group and is not involved in the bond cleavage reaction. Abstraction of the $\alpha$-hydrogen by the $\mathrm{C}$-terminal carbonyl $\mathrm{O}$ was not considered due to lower basicity of the carbonyl group compared with amino functional group [PA(methyl amine) $=$ $214.9 \mathrm{kcal} \mathrm{mol}^{-1}$ versus PA(methyl acetamide $)=212.4$

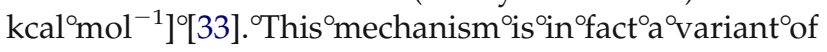

path B of Scheme 1, but with a stronger base and less steric constraint (4-membered ring versus 8-membered ring transition state).

The $\mathrm{C}-\mathrm{S}$ bond cleavage mechanism shown in Scheme 5 is similar to condensed phase Grob fragmentation $[31,32],{ }^{\text {ow }}$ where ${ }^{\circ}$ the ${ }^{\circ}$ ucleophile ${ }^{\circ} s^{\circ}$ the ${ }^{\circ} \mathrm{N}$-terminal ${ }^{\circ}$ amino $\mathrm{N}$ (path $\mathrm{CS}_{\mathrm{g}} \mathrm{A}$ ), C-terminal amide $\mathrm{N}$ (path $\mathrm{CS}_{\mathrm{g}} \mathrm{B}$ ), or C-terminal carbonyl $\mathrm{O}$ (path $\mathrm{CS}_{\mathrm{g}} \mathrm{C}$ ), to form cyclic disulfide product ions $(\mathbf{L})$, $(\mathbf{M})$, or $(\mathbf{N})$, respectively. A combination of two neutrals, (an acrylic acid derivative and $\mathrm{NH}_{3}$ ) are eliminated during this fragmentation process. In the next sections we model the various competing S-S and C-S bond cleavage processes using theoretical calculations; these competing mechanisms were then compared with each other and with amide bond cleavage processes.

\section{Computational Studies on Disulfide Bond Cleavage Reactions}

We have modeled the $\mathrm{S}-\mathrm{S}$ and $\mathrm{C}-\mathrm{S}$ bond cleavage reactions using $(\mathrm{CysNHMe})_{2}$ at the $\mathrm{B} 3 \mathrm{LYP} / 3-21 \mathrm{G}(\mathrm{d})$ 


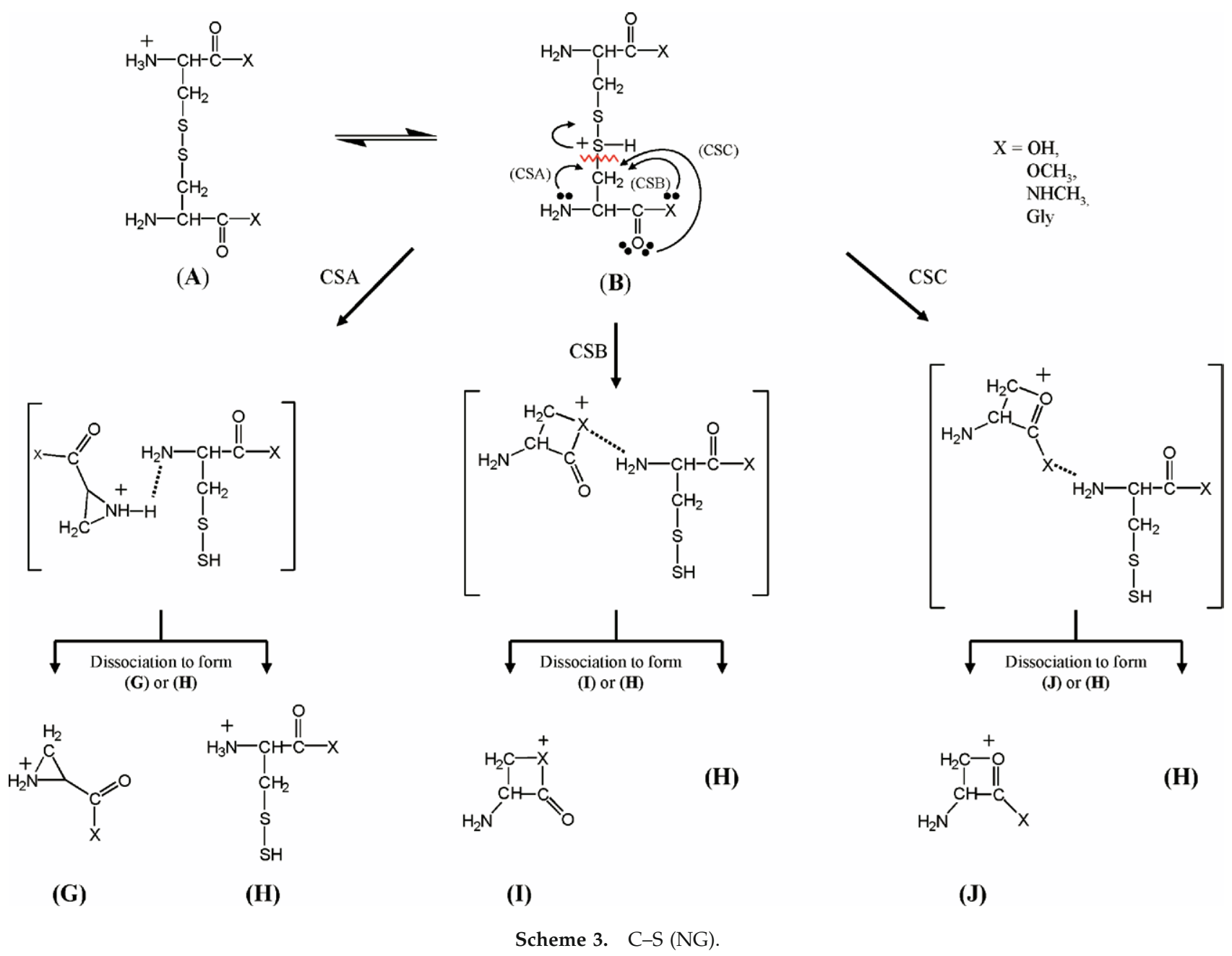

level of theory, and the single point energy was further calculated at the MP2/6-311 + G(2d,p)//B3LYP/3$21 \mathrm{G}(\mathrm{d})$ level of theory.

\section{S-S Bond Cleavage Reaction by Neighboring Group Processes}

Figure $^{\circ} 2^{\circ}$ shows $^{\circ}$ the $^{\circ}$ optimized ${ }^{\circ}$ structures ${ }^{\circ}$ for ${ }^{\circ}$ the ${ }^{\circ}$ most energetically preferable pathway for breaking $\mathrm{S}-\mathrm{S}$ bond (path SSB in Scheme 2) at the B3LYP/3-21G(d) level of theory, including the relative energies (relative to the global minimum Structure A), which were calculated at the MP2/6-311 + G(2d,p)//B3LYP/3-21G(d) level of theory. In this pathway, $\mathrm{S}-\mathrm{S}$ bond cleavage is effected by nucleophilic attack by C-terminal amide $\mathrm{N}$ to form either a protonated sulfenyl amide (Structure E) or protonated cysteine N-methyl amide (Structure D). This pathway has a calculated transition-state energy of $+40.3^{\circ} \mathrm{kcal}^{\circ} \mathrm{mol}^{-1^{\circ}}$ (TS-SSB in ${ }^{\circ}$ Figure $\left.{ }^{\circ} 2\right) .{ }^{\circ}$ However, ${ }^{\circ}$ the endothermicity $\left(\Delta \mathrm{E}_{\mathrm{R}}\right)$ of the reaction to form protonated sulfenyl amide (E) and neutral cysteine-N-methyl amide CysNHMe was predicted to be slightly higher at $+44.7 \mathrm{kcal} \mathrm{mol}^{-1}$. On the other hand, the energy of reaction $\left(\Delta \mathrm{E}_{\mathrm{R}}\right)$ is lower at $+37.5 \mathrm{kcal} \mathrm{mol}^{-1}$ if proton transfer ${ }^{\circ}$ occurred $^{\circ}$ within $^{\circ}$ the ${ }^{\circ}$ ion-molecule ${ }^{\circ}$ complex $^{\circ}[29]$ to form protonated CysNHMe (Structure D) and neutral sulfenyl amide. Interestingly, related sulfenyl amide structures have previously been proposed as intermediates in the regulation of cysteine dependent enzyme, the ${ }^{\text {op }}$ rotein tyrosine ${ }^{\circ}$ phosphatase $1 \mathrm{~B}^{\circ}[34$, \%3]. It should be noted that sulfenyl amide (E) is protonated at the N-terminal amino group, which cannot be formed by simple separation of ion-molecule complex after transition-state ${ }^{\circ}$ TS-SSB (Figure 2 ). ${ }^{\circ}$ Instead, ${ }^{\circ}{ }^{\circ}{ }^{\circ}$ is ${ }^{\circ}$ formed by a second subsequent intramolecular proton transfer process from protonated CysNHMe. This process is related to the proton transport catalyzed isomerization reactions ${ }^{\circ}$ described ${ }^{\circ} y^{\circ} B^{\circ}{ }^{\circ} e^{\circ}[36] .{ }^{\circ}$ The $^{\circ}$ endothermicity for formation of protonated sulfenyl amide by simple bond lengthening from the ion-molecule complex was calculated to be very high at $+63.3 \mathrm{kcal} \mathrm{mol}^{-1}$ (data not shown).

Structures E and D are possible product ion structures for $m / z 133$ and 135 observed in the MS/MS of protonated (CysNHMe) ${ }_{2}$, respectively $^{\circ}\left(\right.$ Figure $^{\circ}$ 1c). ${ }^{\circ}$ Since the endothermicities for the formation of both product ions are close to the transition-state energy, the formation of both product ions is accessible with equal probability during CID of protonated (CysNHMe $)_{2}$. The optimized structures for species related in other path- 


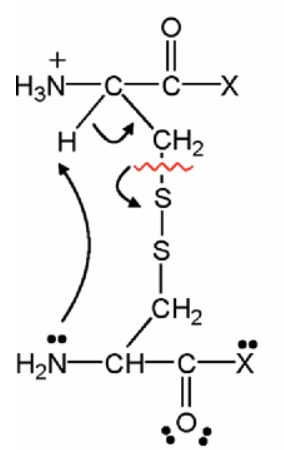

(A)
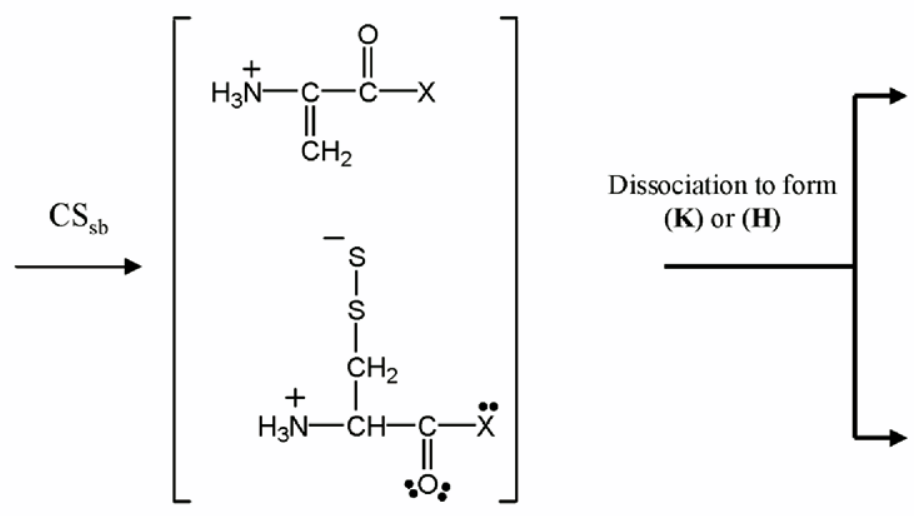<smiles>[X]C(=O)C(=C)[NH3+]</smiles>

$(\mathbf{K})$

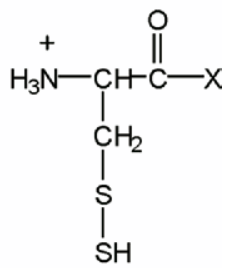

(H)

$$
\begin{aligned}
\mathrm{X}= & \mathrm{OH}, \\
& \mathrm{OCH}_{3}, \\
& \mathrm{NHCH}_{3}, \\
& \text { Gly }
\end{aligned}
$$

Scheme 4. C-S (salt bridge).

ways (paths SSA and SSC) are shown in Figures S3 and S4 supplementary Figures S3 and S4, respectively.

\section{C-S Bond Cleavage Reaction by Neighboring Group Processes}

Figure $3^{\circ}$ shows ${ }^{\text {the }} \mathrm{optimized}^{\circ}$ structures ${ }^{\circ}$ and their $^{\circ}$ relative energies (relative to the global minimum Structure A) for the lowest energy pathway to breaking the $\mathrm{C}-\mathrm{S}$ bond via charge directed neighboring group mechanism (path CSC shown in Scheme 3). In path CSC, C-S bond cleavage is effected by nucleophilic attack of $\beta$-carbon by $\mathrm{C}$-terminal carbonyl $\mathrm{O}$ to form a 4-membered cyclic product ion (Structure J), with a predicted transition-state barrier of $55.9 \mathrm{kcal} \mathrm{mol}^{-1}$. It is interesting to note that this mechanism does not involve S-protonated (CysNHMe) $)_{2}$ structure. Instead, transition-state TS-CSC is a concerted transition state for intramolecular proton transfer from $\mathrm{C}$-terminal carbonyl $\mathrm{O}$ to disulfide group and nucleophilic attack to form the 4-membered product

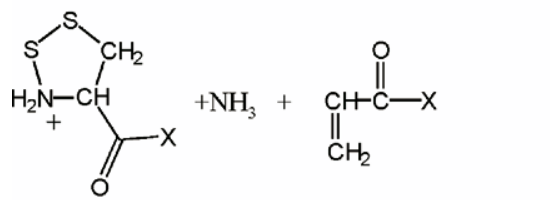

(L)

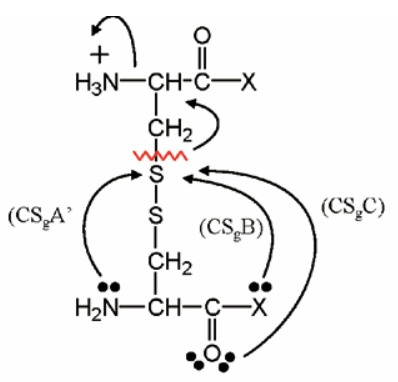

(A)

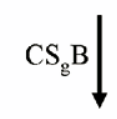<smiles></smiles>

(M)

$$
\begin{aligned}
\mathrm{X}= & \mathrm{OH}, \\
& \mathrm{OCH}_{3}, \\
& \mathrm{NHCH}_{3}, \\
& \mathrm{Gly}
\end{aligned}
$$

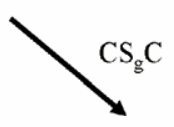<smiles>[X]C1=C(N)CSO[NH2+]1</smiles><smiles>[X]C(=O)C=C</smiles>

(N)

Scheme 5. C-S (Grob). 


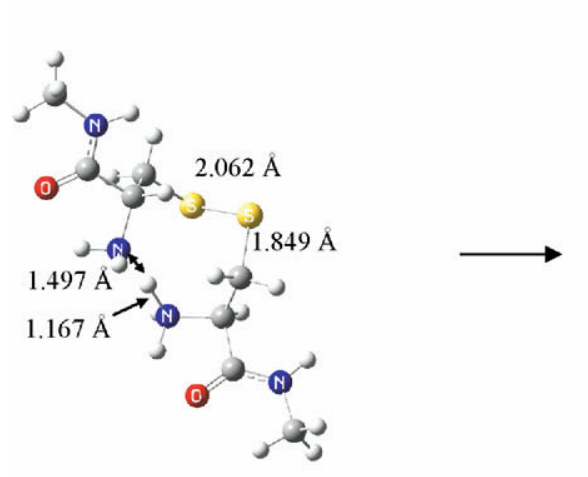

(A) $0.0 \mathrm{kcal} \mathrm{mol}^{-1}$

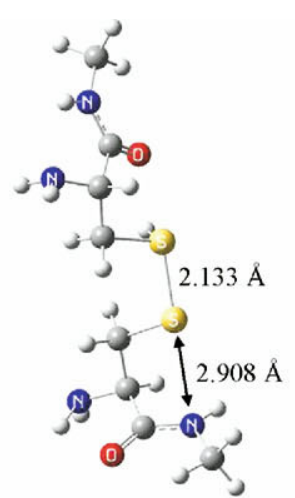

$+33.6 \mathrm{kcal} \mathrm{mol}^{-1}$

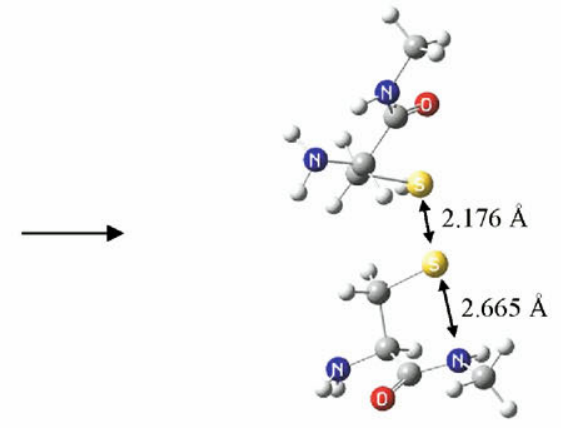

(TS-SSB)

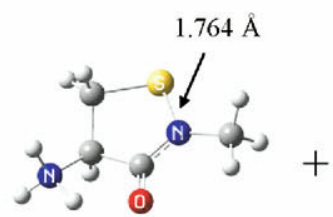

(E)

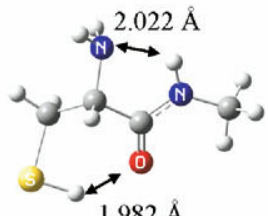

$1.982 \AA$

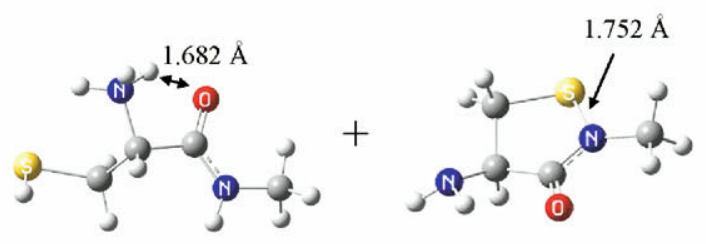

(D)

$+44.7 \mathrm{kcal} \mathrm{mol}^{-1}$

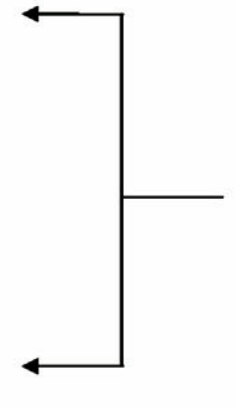

$+37.5 \mathrm{kcal} \mathrm{mol}^{-1}$

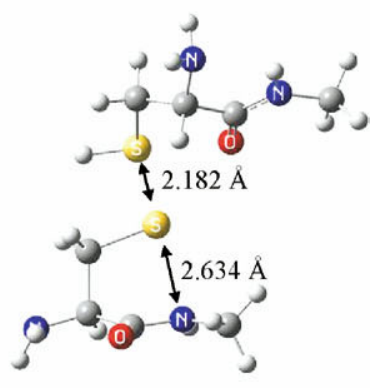

$+37.9 \mathrm{kcal} \mathrm{mol}^{-1}$

Figure 2. MP2/6-311 $+\mathrm{G}(2 \mathrm{~d}, \mathrm{p}) / / \mathrm{B} 3 \mathrm{LYP} / 3-21 \mathrm{G}(\mathrm{d})$ optimized structures and relative energies showing the reaction coordinate for the lowest energy pathway for S-S bond cleavage via neighboring group attack by C-terminal amide N (pathway SSB shown in Scheme 2). All reported energy values are relative to global minimum A. All other pathways in Scheme $\mathbf{2}$ (pathways SSA and SSC) are shown in Figures S2 and S3 supplementary Figures S2 and S3.

ion. Due to the strain in the 4-membered ring product ion Structure J, this pathway has a very high endothermicity $\left(\Delta \mathrm{E}_{\mathrm{R}}\right)$ of $+63.1 \mathrm{kcal} \mathrm{mol}^{-1}$. The product of intramolecular proton transfer to form protonated thiocysteine $\mathrm{N}$-methyl amide (Structure $\mathbf{H}$ ) also has a high endothermicity $\left(\Delta \mathrm{E}_{\mathrm{R}}\right)$ of $+64.0 \mathrm{kcal} \mathrm{mol}^{-1}$. Due to the high-energy barrier for this process, this mechanism is expected to be insignificant in C-S bond cleavage. The optimized structures and relative energies of the other higher energy pathways CSA and CSB are shown in Figures S5 and S6 supplementary Figures S5 and S6, respectively.

\section{C-S Bond Cleavage Reaction by Salt Bridge Mechanism}

The salt bridge mechanism to cleave C-S bond is similar to the cis- elimination shown in path B of Scheme $\mathbf{1}$, but with a stronger base and larger transition-state ring size. In this mechanism $\left(\mathrm{CS}_{\mathrm{sb}}\right.$ shown in Scheme 4$)$ bond cleavage is induced by abstraction of $\alpha$-hydrogen, which weakens the $\mathrm{C}-\mathrm{S}$ bond and forms a salt bridge intermediate. Additionally, the charge is remote from the reaction centre (N-protonated) and is not involved in the salt bridge mechanism.

Figure $^{\circ} 4^{\circ}$ shows $^{\circ}$ the $^{\circ}$ optimized $^{\circ}$ structures $^{\circ}$ for ${ }^{\circ}$ all species involved in this salt bridge mechanism. This pathway has a transition-state energy of $+35.5 \mathrm{kcal}$ $\mathrm{mol}^{-1}$, and the energy of the reaction $\left(\Delta \mathrm{E}_{\mathrm{R}}\right)$ is +44.2 $\mathrm{kcal} \mathrm{mol}^{-1}$, forming protonated dehydroalanine $\mathrm{N}$ methyl amide (Structure $\mathbf{K}$ ) and neutral thiocysteine $\mathrm{N}$-methyl amide. However, intramolecular proton transfer within the ion-molecule complex can form protonated thiocysteine $\mathrm{N}$-methyl amide (Structure $\mathbf{H}$ ) and neutral dehydroalanine N-methyl amide with a lower endothermicity $\left(\Delta \mathrm{E}_{\mathrm{R}}\right)$ at $+34.4 \mathrm{kcal} \mathrm{mol}^{-1}$. Due to 


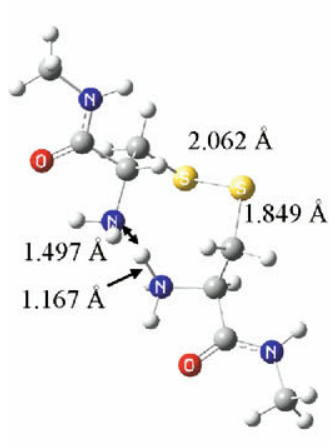

(A) $0.0 \mathrm{kcal} \mathrm{mol}^{-1}$

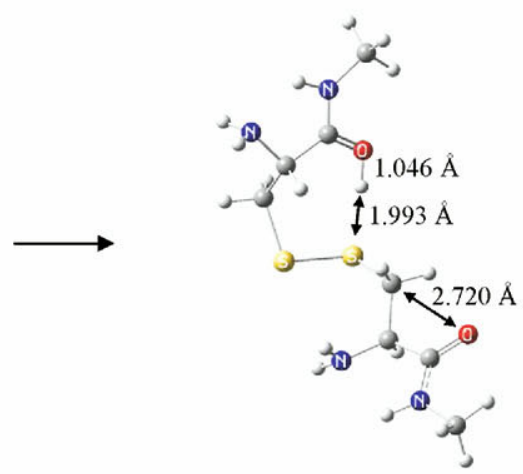

$+17.3 \mathrm{kcal} \mathrm{mol}^{-1}$

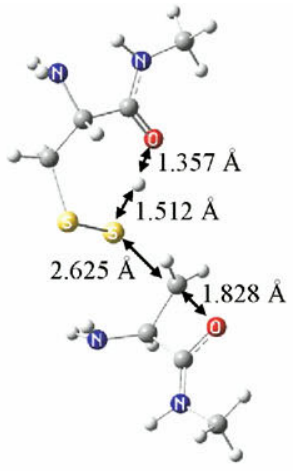

(TS-CSC)

$+55.9 \mathrm{kcal} \mathrm{mol}^{-1}$

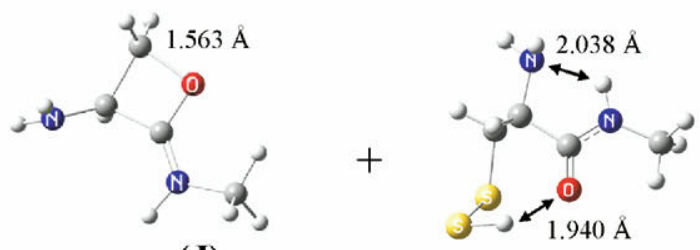

(J)

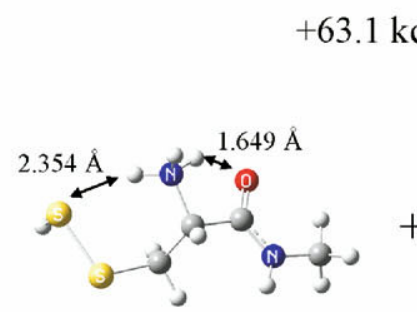

(H)

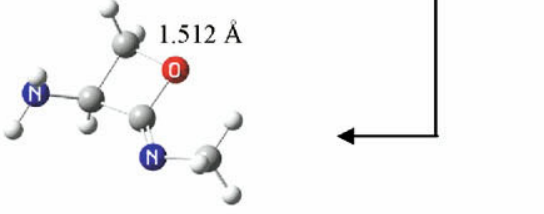

$+64.0 \mathrm{kcal} \mathrm{mol}^{-1}$

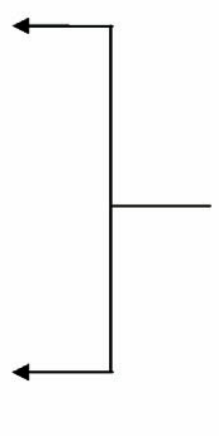

Figure 3. MP2/6-311 + G(2d,p)//B3LYP/3-21G(d) optimized structures and relative energies showing the reaction coordinate for the lowest energy pathway for $\mathrm{C}-\mathrm{S}$ bond cleavage via neighboring group attack by C-terminal carbonyl O (pathway CSC shown in Scheme 3. All reported energy values are relative to global minimum A. All other pathways in Scheme 3 (pathways CSA and CSB) are shown in Figures S4 and S5 supplementary Figures S4 and S5.

the low endothermicity for the formation of Structure $\mathbf{H}$, the salt bridge mechanism is expected to only form $m / z 167$ product ion under low-energy CID MS/MS of $(\text { CysNHMe })_{2} \quad$ Figure $^{\circ}$ 1c). ${ }^{\circ}$ Furthermore, $^{\circ}$ since $^{\circ}$ the $\alpha$-hydrogen has been transferred to the $\mathrm{N}$-thiocysteine methyl amide fragment, this mechanism is consistent with the extensive scrambling observed before formation of thiocysteine N-methyl amide from fragmentation of isotopically labeled $\left(\mathrm{D}_{2}-\mathrm{CysNDMe}\right)_{2^{\circ}}$ (see ${ }^{\circ}$ Figure 1d) ${ }^{\circ}$ and $^{\circ}$ an $^{\circ}$ earlier $^{\circ}$ section $^{\circ}$ for $^{\circ}$ more $^{\circ}$ details $^{\circ}$ about $^{\circ}$ the scrambling of $\alpha$-hydrogen).

Additionally, since the salt bridge mechanism has a much lower energy barrier (+35.0 kcal mol ${ }^{-1}$ ) compared with the neighboring group mechanism, it is expected to be the dominant fragmentation mechanism to explain the $\mathrm{C}-\mathrm{S}$ bond cleavage forming the product ion at $m / z$ 167. Furthermore, this mechanism is triggered by the abstraction of $\alpha$-hydrogen by the basic N-terminal amino group. Thus, increasing the basicity of the N-terminal amino group is expected to decrease the energy barrier for this energetically preferable process. As shown in the fragmentation of protonated $(\mathrm{NMeCysOH})_{2}$, exclusive cleavage of the $\mathrm{C}-\mathrm{S}$ bond is observed to form thiocysteine product ion (see supplementary Figure S2b for the CID MS/MS data of protonated $\left.(\mathrm{NMeCysOH})_{2}\right)$. Thus, this shows that fragmentation can be readily manipulated by chemical derivatization.

$\mathrm{C}-\mathrm{S}$ bond cleavage can also be enhanced by restricting the mobility of the ionizing proton, as clearly demonstrated in the fragmentation of protonated (GCR) $2_{2^{\circ}}$ (Figure 1h). ${ }^{\circ}$ Abundant ${ }^{\circ} \mathrm{C}-\mathrm{S}^{\text {g bond }}{ }^{\circ}$ cleavage ${ }^{\circ}$ to ${ }^{\circ}$ form ${ }^{\circ}$ the ${ }^{\circ}$ protonated thiocysteine derivative $(\mathrm{m} / \mathrm{z} 367)$ and the dehydroalanine derivative $(\mathrm{m} / \mathrm{z} 301)$ is observed in the MS/MS spectrum. Since one of the Arg residues in (GCG) $)_{2}$ is expected to sequester the ionizing proton, fragmentation occurs under nonmobile proton conditions. In addition, the other Arg residue is more basic than the $\mathrm{N}$-terminal amino group 


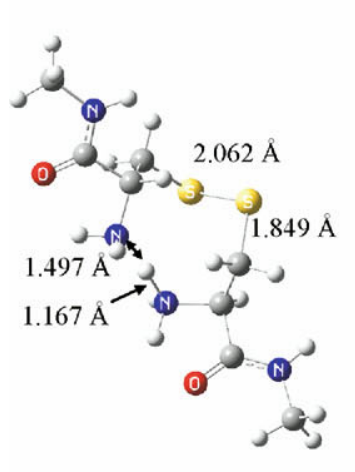

(A) $0.0 \mathrm{kcal} \mathrm{mol}^{-1}$

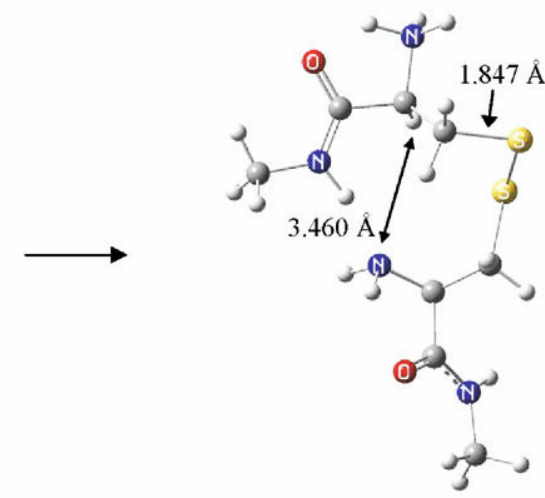

$+7.1 \mathrm{kcal} \mathrm{mol}^{-1}$

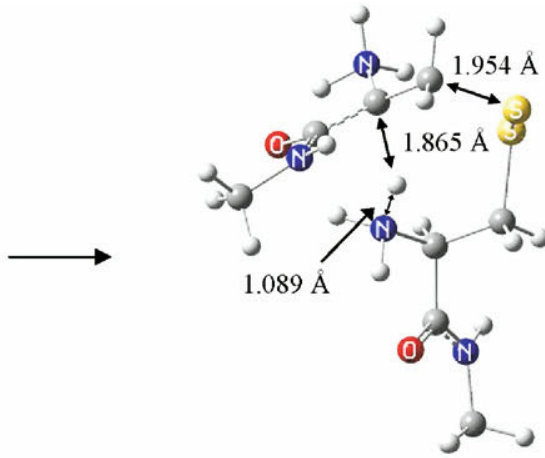

$\left(\mathrm{TS}_{\mathrm{C}} \mathrm{CS}_{\mathrm{sb}}\right)$ $+35.0 \mathrm{kcal} \mathrm{mol}^{-1}$

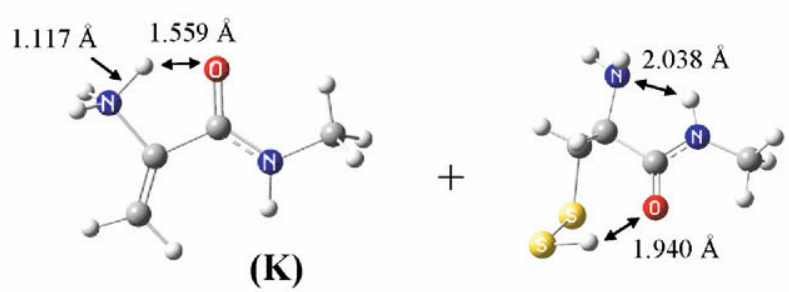

(K)
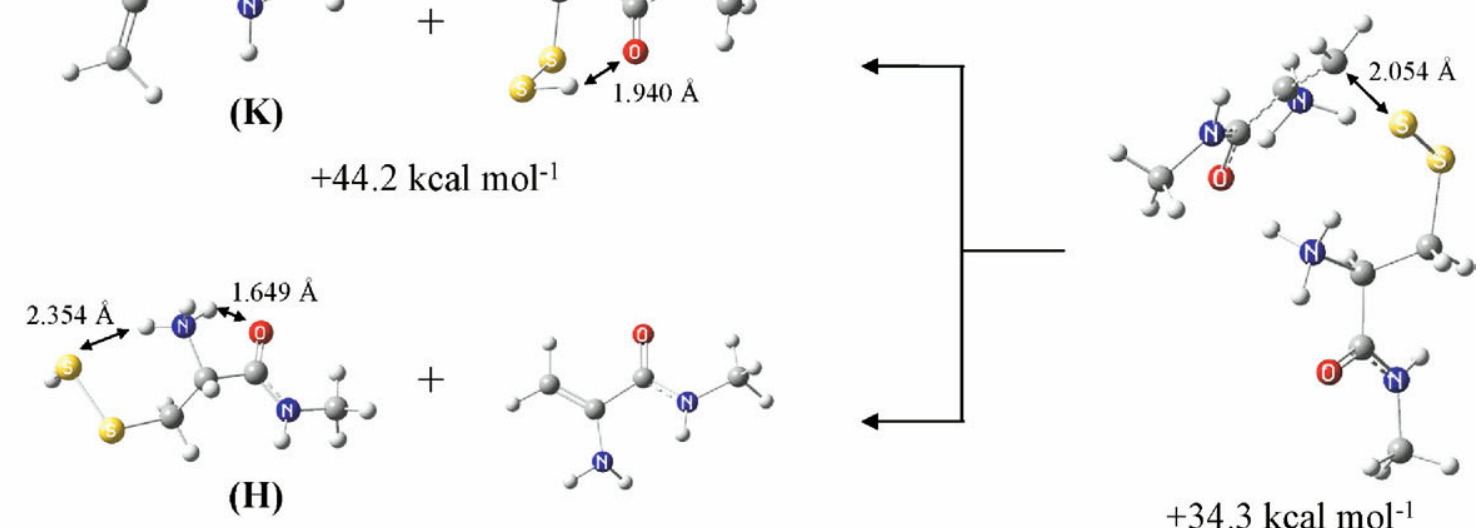

$+34.3 \mathrm{kcal} \mathrm{mol}^{-1}$

$+34.4 \mathrm{kcal} \mathrm{mol}^{-1}$

Figure 4. $\mathrm{MP} 2 / 6-311+\mathrm{G}(2 \mathrm{~d}, \mathrm{p}) / / \mathrm{B} 3 \mathrm{LYP} / 3-21 \mathrm{G}(\mathrm{d})$ optimized structures and relative energies showing the reaction coordinate for the lowest energy pathway for $\mathrm{C}-\mathrm{S}$ bond cleavage via salt bridge mechanism (pathway $\mathrm{CS}_{\mathrm{sb}}$ shown in Scheme 4). All reported energy values are relative to global minimum A.

and is expected to play an important role in the abstraction of the $\alpha$-hydrogen.

\section{C-S Bond Cleavage Reaction by Grob Fragmentation Mechanism}

Figure $^{\circ} 5^{\circ}$ shows $^{\circ}$ the $^{\circ}$ optimized ${ }^{\circ}$ structure ${ }^{\circ}$ for ${ }^{\circ}$ all $^{\circ}$ species involved in the lowest energy pathway for Grob fragmentation mechanism for $\mathrm{C}-\mathrm{S}$ bond cleavage. This lowest energy pathway proceeds via nucleophilic attack by $\mathrm{N}$-terminal amino $\mathrm{N}$ to disulfide group to form dithiazolidine product ion (Structure $\mathbf{L}$ ) and eliminating methylacrylamide and $\mathrm{NH}_{3}$. The transition-state energy for this process was predicted to be $+56.1 \mathrm{kcal} \mathrm{mol}^{-1}$, and the endothermicity of the reaction $\left(\Delta \mathrm{E}_{\mathrm{R}}\right)$ was predicted to be $+57.9 \mathrm{kcal} \mathrm{mol}^{-1}$, clearly higher than the energy barrier for S-S bond cleavage via neighboring group mechanism $\left(+40.3 \mathrm{kcal} \mathrm{mol}^{-1}\right.$ for path SSB) and C $-\mathrm{S}$ bond cleavage via salt bridge mechanism $(+35.0$ $\mathrm{kcal} \mathrm{mol}^{-1}$ ). Since product ion Structure $\mathbf{L}$ is a possible candidate for a product ion structure for $m / z 165$ in the MS/MS of protonated (CysNHMe) $2^{\circ}\left(\right.$ see $^{\circ}$ Figure $\left.1 \mathrm{c}\right)$, , the higher energy barrier for the Grob-type fragmentation mechanism is consistent with the small abundance of this product ion. The optimized structures and relative energies of the other higher energy pathways $\mathrm{CS}_{\mathrm{g}} \mathrm{B}$ and $\mathrm{CS}_{\mathrm{g}} \mathrm{C}$ are shown in Figures S7 and S8 supplementary Figures S7 and S8, respectively.

\section{Summary of the Lowest Energy Pathways for S-S and $\mathrm{C}-\mathrm{S}$ Bond Cleavage}

All the transition-state energies for various competing $\mathrm{S}-\mathrm{S}$ and $\mathrm{C}-\mathrm{S}$ bond cleavage reactions, including the fragmentation pathways shown in the supplementary ${ }^{\circ}$ materials, ${ }^{\circ}$ are $^{\circ}$ summarized $^{\circ}$ in $^{\circ} \mathrm{Table}^{\circ} 2 .^{\circ}$ The $^{\circ}$ energies of reaction $\left(\Delta \mathrm{E}_{\mathrm{R}}\right)$ for each pathway are also included $^{\circ}$ in $^{\circ} \operatorname{Table}^{\circ} 2 .^{\circ} \mathrm{As}^{\circ} \operatorname{can}^{\circ}$ be $^{\circ} \operatorname{seen}^{\circ}$ from $^{\circ} \operatorname{Table}^{\circ} 2$, 


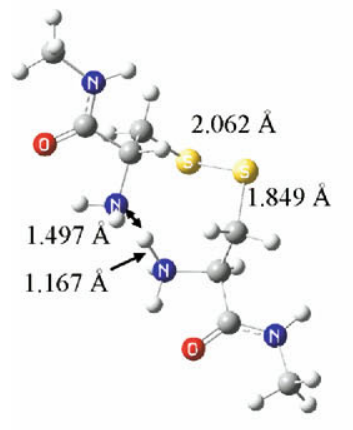

(A) $0.0 \mathrm{kcal} \mathrm{mol}^{-1}$

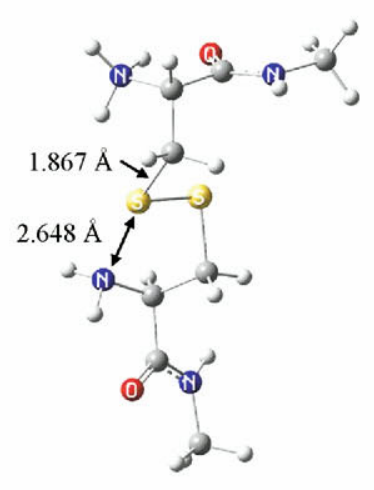

$+14.2 \mathrm{kcal} \mathrm{mol}^{-1}$
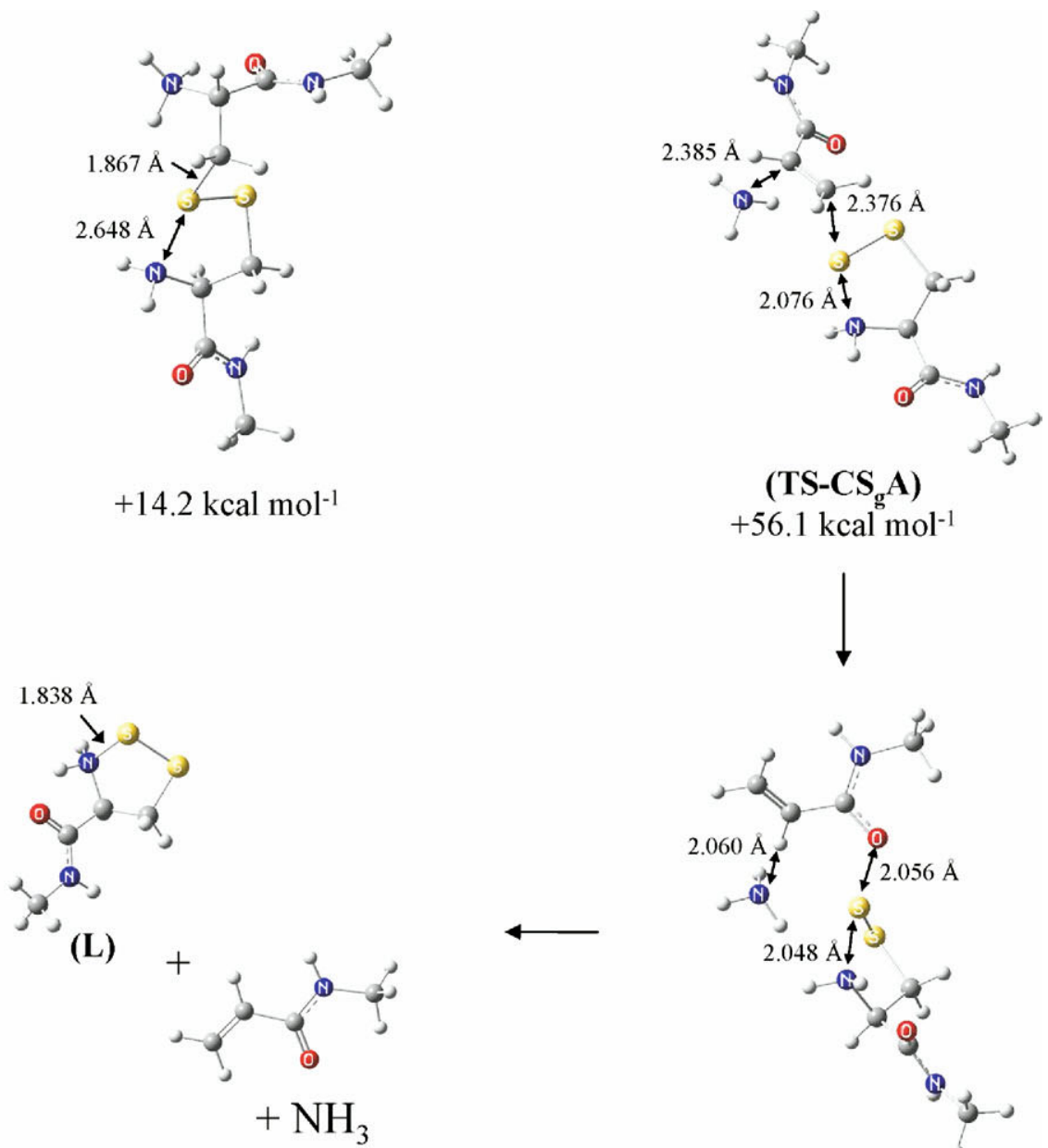

$+57.9 \mathrm{kcal} \mathrm{mol}^{-1}$

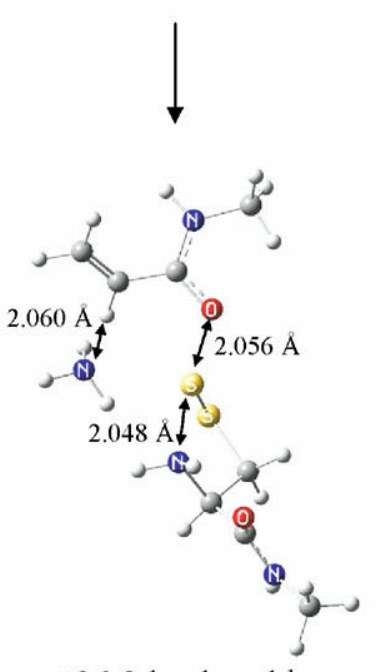

$+36.9 \mathrm{kcal} \mathrm{mol}^{-1}$

Figure 5. MP2/6-311 + G(2d,p)//B3LYP/3-21G(d) optimized structures and relative energies showing the reaction coordinate for the lowest energy pathway for C-S bond cleavage via Grob-type fragmentation whereby the $\mathrm{N}$-terminal amino $\mathrm{N}$ acts as the intramolecular nucleophile (pathway $\mathrm{CS}_{\mathrm{g}} \mathrm{A}$ shown in Scheme 5. All reported energy values are relative to global minimum A. All other pathways in Scheme 5 (pathways $\mathrm{CS}_{\mathrm{g}} \mathrm{B}$ and $\mathrm{CS}_{\mathrm{g}} \mathrm{C}$ ) are shown in supplementary Figures S6 and S7.

some pathways have a higher endothermicity than the transition state, while additional proton transfer step within ion-molecule complexes lowers the endo- thermicity considerably for other pathways. We also have underlined the lowest energy pathway for each mechanism (S-S or C-S bond cleavage) to indicate the

Table 2. Calculated transition energy barrier $\left(\Delta \mathrm{E}^{\ddagger}\right)$ and the relative energy of the separated products $\left(\Delta \mathrm{E}_{\mathrm{R}}\right)$ in parentheses for the competing bond cleavage processes in model system protonated (Cys-NHMe) ${ }_{2}$

\begin{tabular}{|c|c|c|c|}
\hline \multirow[b]{2}{*}{ Types of bond cleavage processes } & \multicolumn{3}{|c|}{$\Delta \mathrm{E}^{\ddagger}, \mathrm{kcal} \mathrm{mol}{ }^{-1}\left(\Delta \mathrm{E}_{\mathrm{R}}, \mathrm{kcal} \mathrm{mol}^{-1}\right)^{\mathrm{a}}$} \\
\hline & Amino-N & Amide- $N$ & Carbonyl-O \\
\hline (1) S-S bond cleavage (NG mechanism) ${ }^{\mathrm{b}}$ & $38.5(58.5,58.4)$ & $40.3(44.7,37.5)$ & $32.2(54.0,60.6)$ \\
\hline (2) C-S bond cleavage (NG mechanism) ${ }^{\mathrm{C}}$ & $76.5(53.8,49.9)$ & $70.6(64.7,43.8)$ & $\underline{55.9(63.1,64.0)}$ \\
\hline (3) C-S bond cleavage (salt-bridge mechanism) ${ }^{d}$ & $35.0(34.4,44.2)$ & - & - \\
\hline (4) C-S bond cleavage (Grob fragmentation) ${ }^{\mathrm{e}}$ & $\underline{56.1(57.9)}$ & $70.8(74.7)$ & $60.2(66.4)$ \\
\hline (5) Amide bond cleavage & \multicolumn{3}{|c|}{$25-40^{f}$} \\
\hline
\end{tabular}

aThe underlined numbers signify the pathway with the lowest energy for each mechanism.

bS-S bond cleavage via neighboring group process with various nucleophiles (see Scheme 2).

${ }^{\circ} \mathrm{C}-\mathrm{S}$ bond cleavage via neighboring group process with various nucleophiles (see Scheme 3 ).

${ }^{\mathrm{d}} \mathrm{C}-\mathrm{S}$ bond cleavage via salt-bridge mechanism (see Scheme 4).

${ }^{e} \mathrm{C}-\mathrm{S}$ bond cleavage via Grob fragmentation using with nucleophiles (see Scheme 5).

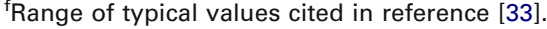




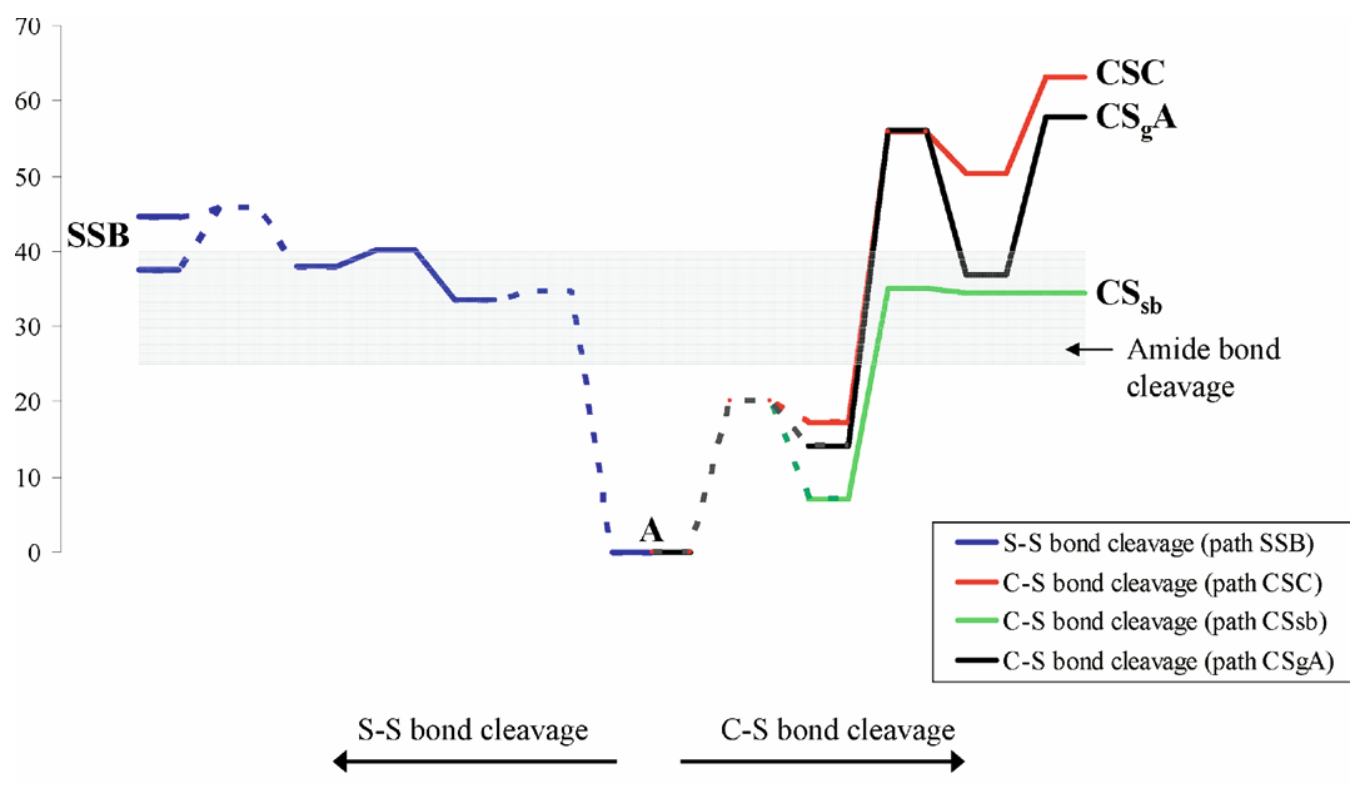

Reaction Coordinate

Figure 6. The MP2/6-311 $+\mathrm{G}(2 \mathrm{~d}, \mathrm{p}) / / \mathrm{B} 3 \mathrm{LYP} / 3-21 \mathrm{G}(\mathrm{d})$ calculated potential energy surfaces (PES) for competing fragmentation pathways of protonated (CysNHMe $)_{2}$. This PES summarizes only the lowest energy pathways for each fragmentation mechanisms shown in Schemes 2-5, and the optimized $^{\circ}$ structures $^{\circ}$ are $^{\circ}$ shown $^{\circ}$ in $^{\circ}$ Figures $\left.^{\circ} 3-6\right) .{ }^{\circ}$ All $^{\circ}$ energies $^{\circ}$ are $^{\circ}$ relative $^{\circ}$ to $^{\circ}$ the $^{\circ}$ global $^{\circ}$ minimum Structure A. Path SSB to cleave S-S bond via neighboring group mechanism is represented by the blue $\mathrm{PES}$, path CSC to cleave C-S bond via neighboring group mechanism is shown in the red PES, path $\mathrm{CS}_{\mathrm{sb}}$ to cleave $\mathrm{C}-\mathrm{S}$ bond via salt bridge mechanism is shown in the green PES, and path $\mathrm{CS}_{\mathrm{g}} \mathrm{A}$ to cleave $\mathrm{C}-\mathrm{S}$ bond via Grob-type fragmentation mechanism is shown in black PES. Dashed lines represent transition states (that were not located) interconnecting conformers.

most probable pathway that can occur from each fragmentation mechanism. These results are also summarized $^{\circ}$ in $^{\circ}$ Figure $^{\circ} 6,^{\circ}$ which ${ }^{\circ}$ shows $^{\circ}$ the ${ }^{\circ}$ lowest energy potential energy surfaces from each fragmentation mechanism (both S-S and C-S bond cleavage). It should be noted that some transition states for bond rotations and intramolecular proton transfer processes were not calculated, and are thus represented by dotted lines.

For all the mechanisms considered, path $\mathrm{CS}_{\mathrm{sb}}$ to cleave the $\mathrm{C}-\mathrm{S}$ bond is the lowest energy process and is expected to dominate the fragmentation pathway. This is consistent with the CID spectrum of (CysNHMe $)_{2}$, which shows the formation of thiocysteine N-methyl amide at $\mathrm{m} / \mathrm{z} 167$ to be the most dominant product ion. S-S bond cleavage process by neighboring group (path SSB) is also expected to be a dominant process due to its rather low-energy barrier. This is also highlighted in the abundant formation of protonated sulfenyl amide $(\mathrm{m} / \mathrm{z} 133)$ and protonated CysNHMe ( $m / z$ 135) in the MS/MS spectrum of $(\mathrm{CysNHMe})_{2}$ (Figure $\left.{ }^{\circ} 1 \mathrm{c}\right) .^{\circ}{ }^{\circ}$ The $^{\circ}$ Grob-like fragmentation mechanism (path $\mathrm{CS}_{\mathrm{g}} \mathrm{A}$ ) is expected to form a small abundance of dithiazolidine product ion due to the reasonably high-energy barrier for this process. Finally, the neighboring group process to cleave C-S bond (path CSC) is expected not to operate due to the high-energy barrier of the process.

\section{When Will Disulfide Bond Cleavage Occur?}

From $^{\circ}$ Table $^{\circ} 2^{\circ}$ and ${ }^{\circ}$ Figure $^{\circ} 6,{ }^{\circ}$ clearly $^{\circ}$ there ${ }^{\circ}$ are ${ }^{\circ}$ various competing pathways for $\mathrm{S}-\mathrm{S}$ and $\mathrm{C}-\mathrm{S}$ bond cleavage processes, which can complicate the fragmentation behavior of protonated peptide containing disulfide bonds. However, these competing processes are in fact much higher in energy than typical amide bond cleavages. ${ }^{\circ}$ For $^{\circ}$ example, ${ }^{\circ}$ in ${ }^{\circ}$ Figure $^{\circ} 6^{\circ}$ the ${ }^{\circ}$ typical ${ }^{\circ}$ energetic requirement to cleave amide bonds or eliminate neutral molecules ${ }^{\circ}[37]^{\circ}$ were $^{\circ}$ included $^{\circ}$ as $^{\circ} a^{\circ}$ band $^{\circ}$ of ${ }^{\circ}$ energy between $25^{\circ}$ to $^{\circ} 40^{\circ} \mathrm{kcal}^{\circ} \mathrm{mol}^{-1}{ }^{\circ}{ }^{\circ} \mathrm{As}^{\circ} \mathrm{can}^{\circ} \mathrm{be}^{\circ}$ seen $^{\circ}{ }^{\circ}{ }^{\circ} \mathrm{Figure}^{\circ} 6$, most disulfide bond cleavage processes ( $\mathrm{S}-\mathrm{S}$ and $\mathrm{C}-\mathrm{S}$ bond cleavage) lie outside the band of energy required to cleave an amide bond in a peptide, with the exception of the salt bridge mechanism to cleave the $\mathrm{C}-\mathrm{S}$ bond. This is further illustrated in the CID MS/MS fragmentation of the heterodimer of AcCysNHMe-CysNHMe, linked by a disulfide bond (see supplementary Figure S2c). In this system, various fragmentation processes can occur under CID, including amide, S-S, and C-S bond cleavages. However fragmentation is dominated by amide bond cleavage via elimination of $\mathrm{CH}_{3} \mathrm{NH}_{2}$, and no disulfide bond cleavage is observed (see supplementary Figure S2c).

How then, can disulfide bond cleavage reactions be promoted in larger peptides? Clearly for this to happen, access to an enolate anion is desirable. This can be achieved in two ways: (1) via negative ion CID experi- 
ment $^{\circ}\left[38,{ }^{\circ} 39\right],,^{\circ}$ as $^{\circ}$ recently $^{\circ}$ demonstrated $^{\circ}$ in $^{\circ} \mathrm{a}^{\circ}$ joint experimental and theoretical study by Bowie and coworkers ${ }^{\circ}\left[40,{ }^{\circ} 41\right]^{\circ}{ }^{\circ}$ and $^{\circ}(2)^{\circ}{ }^{\circ} n^{\circ}$ protonated $^{\circ}$ peptides $^{\circ}$ that have nonmobile protons, thereby promoting the salt bridge mechanism (c.f. Scheme 4). Interestingly, this last factor might explain the prevalence of disulfide bond cleavage ${ }^{\circ}{ }^{\circ} \mathrm{MALDI}^{\circ}$ experiment ${ }^{\circ}[15]$.

\section{Conclusions}

Cystine and its C-terminal derivatives and simple peptides containing intermolecular disulfide bonds fragment via a variety of pathways, including losses of neutral molecules, amide bond cleavage, and S-S and $\mathrm{C}-\mathrm{S}$ bond cleavages. Various mechanisms were considered to explain S-S and C-S bond cleavage processes, including charge directed neighboring group processes and nonmobile proton fragmentation processes. Using theoretical calculations performed on protonated (CysNHMe) ${ }_{2}$ (at the MP2/6$311+\mathrm{G}(2 \mathrm{~d}, \mathrm{p}) / /$ B3LYP/3-21G(d) level of theory) three low-energy fragmentation pathways were identified, which should be energetically accessible during low-energy CID MS/MS experiments: (1) S-S bond cleavage dominated by a neighboring group process involving $\mathrm{C}$-terminal amide $\mathrm{N}$ to form either protonated CysNHMe ( $m / z$ 135) or protonated sulfenyl amide product ion $(\mathrm{m} / \mathrm{z} 133)$ (path SSB of Scheme 2); (2) C-S bond cleavage process is dominated via a salt bridge mechanism, involving the $\alpha$-hydrogen to form protonated thiocysteine N-methyl amide $(\mathrm{m} / \mathrm{z}$ $167)^{\circ}\left(\right.$ Scheme $\left.^{\circ} 4\right)$; ${ }^{\circ}{ }^{\circ} d^{\circ}[3]^{\circ} \mathrm{C}-\mathrm{S}^{\circ}$ bond ${ }^{\circ}$ cleavage ${ }^{\circ}$ process ${ }^{\circ}$ is also dominated by the Grob-like fragmentation where the nucleophile is the $\mathrm{N}$-terminal amino group to form dithiazolidine product ion $\left(\mathrm{m} / \mathrm{z}\right.$ 165) (path $\mathrm{CS}_{\mathrm{g}} \mathrm{A}$ of Scheme 5). Interestingly $\mathrm{C}-\mathrm{S}$ bond cleavage by neighboring group processes (Scheme 3 ) have highenergy barriers and are expected to be inaccessible energetically during CID MS/MS experiment. In comparison to simple amide bond cleavage, these processes are higher in energy, explaining why disulfide bond cleavage processes are rarely observed for low-energy CID fragmentation of peptide ions containing disulfide bonds which have mobile proton(s).

This study highlights the complexity of fragmentation reactions for even such a small system as the cystine derivative, $(\mathrm{CysNHMe})_{2}$. In fact, the disulfide bond brings a range of potentially reactive functional groups (nucleophile and electrophile) into close proximity, allowing different reactions to compete. The presence of an intermolecular disulfide bond also allows other fragmentation pathways such as the salt bridge mechanism to occur, which are uncommon in

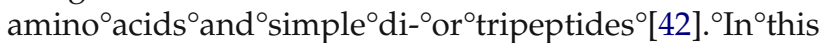
work, product ion stabilities were shown to be an important factor in determining the lowest energy fragmentation pathway. Finally, this study further highlights the importance of the role of mobile proton in dictating the types of fragmentation reactions observed under low-energy CID. Disulfide bond cleavage reactions in protonated peptides join the pantheon of nonmobile proton reactions, which include C-terminal aspartic acid (and to a lesser extent glutamic acid cleavage $)^{\circ}\left[43,{ }^{\circ} 44\right]^{\circ}$ and ${ }^{\circ} \mathrm{CH}_{3} \mathrm{SOH}$ loss from methionine sulfoxide-containing ${ }^{\circ}$ peptides ${ }^{\circ}[6,7]$.

\section{Acknowledgments}

The authors thank ARC for financial support via grant DP0558430 (to RAJO) and the ARC Centre of Excellence in Free Radical Chemistry and Biotechnology. They thank VICS for the Chemical Sciences High Performance Computing Facility, and Dr. Gavin Reid for helpful discussions. HL acknowledges the award of an Elizabeth and Vernon Puzey Postgraduate Scholarship.

\section{References}

1. O'Hair, R. A. J. The Role of Nucleophile- Electrophile Interactions in the Unimolecular and Bimolecular Gas-Phase Ion Chemistry of Peptides and Related Systems. J. Mass Spectrom. 2000, 35, 1377-1381.

2. Paizs, B.; Suhai, S. Fragmentation Pathways of Protonated Peptides. Mass Spectrom. Rev. 2005, 24, 508-548.

3. Bowie, J. H.; Brinkworth, C. S.; Dua, S. Collision-Induced Fragmentations of the $[\mathrm{M}-\mathrm{H}]^{-}$Parent Anions of Underivatized Peptides: An Aid to Structure Determination and Some Unusual Negative Ion Cleavages. Mass Spectrom. Rev. 2002, 21, 87-107.

4. Jensen, O. N. Modification-Specific Proteomics: Characterization of Post-Translational Modifications by Mass Spectrometry. Curr. Op. Chem. Biol. 2004, 8, 33-41.

5. Mann, M.; Jensen, O. N. Proteomic Analysis of Post-Translational Modifications. Nat. Biotech. 2003, 21, 255-261.

6. O'Hair, R. A. J.; Reid, G. E. Neighboring Group Versus cis-Elimination Mechanisms for Side Chain Loss from Protonated Methionine, Methionine Sulfoxide, and Their Peptides. Eur. J. Mass Spectrom. 1999, 5, 325-334.

7. Reid, G. E.; Roberts, K. D.; Kapp, E. A.; Simpson, R. J. Statistical and Mechanistic Approaches to Understanding the Gas-Phase Fragmentation Behavior of Methionine Sulfoxide Containing Peptides. J. Proteome Res. 2004, 3, 751-759.

8. Reid, G. E.; Simpson, R. J.; O'Hair, R. A. J. Leaving Group and Gas Phase Neighboring Group Effects in the Side Chain Losses from Protonated Serine and Its Derivatives. J. Am. Soc. Mass Spectrom. 2000, 11, 10471060.

9. Gorman, J. J.; Wallis, T. P.; Pitt, J. J. Protein Disulfide Bond Determination by Mass Spectrometry. Mass Spectrom. Rev. 2002, 21, 183-216.

10. Zubarev, R. A.; Kruger, N. A.; Fridriksson, E. K.; Lewis, M. A.; Horn, D. M.; Carpenter, B. K.; McLafferty, F. W. Electron Capture Dissociation of Gaseous Multiply-Charged Proteins is Favored at Disulfide Bonds and Other Sites of High Hydrogen Atom Affinity. J. Am. Chem. Soc. 1999, 121, 2857-2862.

11. Fung, Y. M. E.; Kjeldsen, F.; Silivra, O. A.; Chan, T. W. D.; Zubarev, R. A. Facile Disulfide Bond Cleavage in Gaseous Peptide and Protein Cations by Ultraviolet Photodissociation at $157 \mathrm{~nm}$. Angew. Chem. Int. Ed. 2005, 44, 6399-6403.

12. Gunawardena, H. P.; O'Hair, R. A. J.; McLuckey, S. A. Selective Disulfide Bond Cleavage in Gold(I) Cationized Polypeptide Ions Formed via Gas-Phase Ion/Ion Cation Switching. J. Proteome Res. 2006, 5, 2087-2092.

13. Loo, J. A.; Edmonds, C. G.; Udseth, H. R.; Smith, R. D. Effect of Reducing Disulfide-Containing Proteins on Electrospray Ionization Mass Spectra. Anal. Chem. 1990, 62, 693-698.

14. Wu, J.; Watson, J. T. A Novel Methodology for Assignment of Disulfide Bond Pairings in Proteins. Prot. Sci. 1997, 6, 391-398.

15. Jones, M. D.; Patterson, S. D.; Lu, H. S. Determination of Disulfide Bonds in Highly Bridged Disulfide-Linked Peptides by Matrix-Assisted Laser Desorption/Ionization Mass Spectrometry with Postsource Decay. Anal. Chem. 1998, 70, 136-143.

16. Wells, J. M.; Stephenson, J. L.; McLuckey, S. A. Charge Dependence of Protonated Insulin Decompositions. Int. J. Mass Spectrom. 2000, 203, A1-A9.

17. Wysocki, V. H.; Tsaprailis, G.; Smith, L. L.; Breci, L. A. Mobile and Localized Protons: A Framework for Understanding Peptide Dissociation. J. Mass Spectrom. 2000, 35, 1399-1406.

18. Kapp, E. A.; Schütz, F.; Reid, G. E.; Eddes, J. S.; Moritz, R. L.; O'Hair, R. A. J.; Speed, T. P.; Simpson, R. J. Mining a Tandem Mass Spectrometry Database To Determine the Trends and Global Factors Influencing Peptide Fragmentation. Anal. Chem. 2003, 75, 6251-6264.

19. Rubino, F. M.; Verduci, C.; Giampiccolo, R.; Pulvirenti, S.; Brambilla, G.; Colombi, A. Characterization of the Disulfides of Biothiols by Electrospray Ionization and Triple-Quadrupole Tandem Mass Spectrometry. J. Mass Spectrom. 2004, 39, 1408-1416. 
20. de Moraes, P. R. P.; Linnert, H. V.; Aschi, M.; Riveros, J. M. Experimental and Theoretical Characterization of Long-Lived Triplet State $\mathrm{CH}_{3} \mathrm{CH}_{2} \mathrm{~S}^{+}$Cations. J. Am. Chem. Soc. 2000, 122, 10133-10142.

21. Freitas, M. A.; O'Hair, R. A. J.; Williams, T. D. Gas-Phase Reactions of Cysteine with Charged Electrophiles: Regioselectivities of the Dimethylchlorinium Ion and the Methoxymethyl Cation. J. Org. Chem. 1997, 62, 6112-6120.

22. Reid, G. E.; Simpson, R. J.; O'Hair, R. A. J. A Mass Spectrometric and ab Initio Study of the Pathways for Dehydration of Simple Glycine and Cysteine-Containing Peptide $[\mathrm{M}+\mathrm{H}]^{+}$Ions. J. Am. Soc. Mass Spectrom. 1998, 9, 945-956.

23. Feenstra, R. W.; Stokkingreef, E. H. M.; Reichwein, A. M.; Lousberg, W. B. H.; Ottenheijm, H. C. J. Oxidative Preparation of Optically Active N-Hydroxy- $\alpha$-Amino Acid Amides. Tetrahedron 1990, 46, 1745-1756.

24. Frisch, M. J.; Trucks, G. W.; Schlegel, H. B.; Scuseria, G. E.; Robb, M. A.; Cheeseman, J. R.; Montgomery, J. A., Jr.; Vreven, T.; Kudin, K. N.; Burant, J. C.; Millam, J. M.; Iyengar, S. S.; Tomasi, J.; Barone, V.; Mennucci, B.; Cossi, M.; Scalmani, G.; Rega, N.; Petersson, G. A.; Nakatsuji, H.; Hada, M.; Ehara, M.; Toyota, K.; Fukuda, R.; Hasegawa, J.; Ishida, M.; Nakajima, T.; Honda, Y.; Kitao, O.; Nakai, H.; Klene, M.; Li, X.; Knox, J. E.; Hratchian, H. P.; Cross, J. B.; Adamo, C.; Jaramillo, J.; Gomperts, R.; Stratmann, R. E.; Yazyev, O.; Austin, A. J.; Cammi, R.; Pomelli, C.; Ochterski, J. W.; Ayala, P. Y.; Morokuma, K.; oth, G. A.; Salvador, P.; Dannenberg, J. J.; Zakrzewski, V. G.; Dapprich, S.; Daniels, A. D.; Strain, M. C.; Farkas, O.; Malick, D. K.; Rabuck, A. D.; Raghavachari, K.; Foresman, J. B.; Ortiz, J. V.; Cui, Q.; Baboul, A. G.; Clifford, S.; Cioslowski, J.; Stefanov, B. B.; Liu, G.; Liashenko, A.; Piskorz, P.; Komaromi, I.; Martin, R. L.; Fox, D. J.; Keith, T.; Al-Laham, M. A.; Peng, C. Y.; Nanayakkara, A.; Challacombe, M.; Gill, P. M. W.; Johnson, B.; Chen, W.; Wong, M. W.; Gonzalez, C.; Pople J. A. Gaussian 03 (Rev B.04); Gaussian, Inc.: Pittsburgh PA, 2003.

25. Turecek, F. Proton Affinity of Dimethyl Sulfoxide and Relative Stabilities of $\mathrm{C}_{2} \mathrm{H}_{6} \mathrm{OS}$ Molecules and $\mathrm{C}_{2} \mathrm{H}_{7} \mathrm{OS}^{+}$Ions. A Comparative G2(MP2) ab Initio and Density Functional Theory Study. J. Phys. Chem. A 1998, 102, 4703-4713.

26. Keith, T.; Millam, J.; Eppinnett, K.; Hovell, W. L.; Gilliland, R. GaussView (Ver 3.0) Dennington II, R. Semichem, Inc.: Shawnee Mission, KS, 2003.

27. Lioe, H.; O'Hair, R. A. J.; Reid, G. E. Gas-Phase Reactions of Protonated Tryptophan. J. Am. Soc. Mass Spectrom. 2004, 15, 65-76.

28. Lioe, H.; O'Hair, R. A. J. Neighboring Group Processes in the Deamination of Protonated Phenylalanine Derivatives. Org. Biomol. Chem. 2005, 3, 3618-3628.

29. Bowen, R. D. Ion-Neutral Complexes. Acc. Chem. Res. 1991, 24, 364-371.

30. Morgan, D. G.; Bursey, M. M. A Linear Free-Energy Correlation in the Low-Energy Tandem Mass Spectra of Protonated Tripeptides Gly-GlyXxx. Org. Mass Spectrom. 1994, 29, 354-359.

31. Grob, C. A. Mechanisms and Stereochemistry of Heterolytic Fragmentation. Angew. Chem. Int. Ed. 1969, 8, 535-546.
32. Kurti, L.; Czako, B. In Strategic Applications of Named Reactions in Organic Synthesis: Background and Detailed Mechanisms; Elsevier Academic: Burlington, 2005; p 190.

33. Hunter, E. P.; Lias, S. G. Proton Affinity Evaluation. In NIST Chemistry WebBook, NIST Standard Reference Database Number 69; Linstrom, P. J. Mallard, W. G.; National Institute of Standards and Technology: Gaithersburg, MD, 20899 (http://webbook.nist.gov/cgi/cbook.cgi? Contrib-), June 2005.

34. Salmeen, A.; Andersen Jannik, N.; Myers Michael, P.; Meng, T.-C.; Hinks John, A.; Tonks Nicholas, K.; Barford, D. Redox Regulation of Protein Tyrosine Phosphatase 1B Involves a Sulphenyl-Amide Intermediate. Nature 2003, 423, 769-773.

35. van Montfort-Rob, L. M.; Congreve, M.; Tisi, D.; Carr, R.; Jhoti, H. Oxidation State of the Active-Site Cysteine in Protein Tyrosine Phosphatase 1B. Nature 2003, 423, 773-777.

36. Bohme, D. K. Proton Transport in the Catalyzed Gas-Phase Isomerization of Protonated Molecules. Int. J. Mass Spectrom. Ion Processes 1992 115, 95-110.

37. Amunugama, M.; Roberts, K. D.; Reid, G. E. Mechanisms for the Selective Gas-Phase Fragmentation Reactions of Methionine Side Chain Fixed Charge Sulfonium Ion Containing Peptides. J. Am. Soc. Mass Spectrom. 2006, 17, 1631-1642.

38. Zhou, J.; Ens, W.; Poppeschriemer, N.; Standing, K. G.; Westmore, J. B. Cleavage of Interchain Disulfide Bonds Following Matrix-Assisted Laser-Desorption. Int. J. Mass Spectrom. Ion Processes 1993, 126, 115-122.

39. Chrisman, P. A.; McLuckey, S. A. Dissociations of Disulfide-Linked Gaseous Polypeptide/Protein Anions: Ion Chemistry with Implications for Protein Identification and Characterization. J. Proteome Res. 2002, 1, 549-557.

40. Bilusich, D.; Maselli, V. M.; Brinkworth, C. S.; Samguina, T.; Lebedev, A. T.; Bowie, J. H. Direct Identification of Intramolecular Disulfide Links in Peptides Using Negative Ion Electrospray Mass Spectra of Underivatized Peptides. A Joint Experimental and Theoretical Study. Rapid Commun. Mass Spectrom. 2005, 19, 3063-3074.

41. Bilusich, D.; Bowie, J. H. Identification of Intermolecular Disulfide Linkages in Underivatized Peptides Using Negative Ion Electrospray Mass Spectrometry. A Joint Experimental and Theoretical Study. Rapid Commun. Mass Spectrom. 2007, 21, 619-628.

42. Farrugia, J. M.; O'Hair, R. A. J. Involvement of Salt Bridges in a Novel Gas-Phase Rearrangement of Protonated Arginine-Containing Dipeptides which Precedes Fragmentation. Int. J. Mass Spectrom. 2003, 222, 229-242.

43. Tsaprailis, G.; Nair, H.; Somogyi, A.; Wysocki, V. H.; Zhong, W.; Futrell, J. H.; Summerfield, S. G.; Gaskell, S. J. Influence of Secondary Structure on the Fragmentation of Protonated Peptides. J. Am. Chem. Soc. 1999, 121, 5142-5154.

44. Bailey, T. H.; Laskin, J.; Futrell, J. H. Energetics of Selective Cleavage at Acidic Residues Studied by Time- and Energy-Resolved SurfaceInduced Dissociation in FT-ICR MS. Int. J. Mass Spectrom. 2003, 222, 313-327. 